\title{
CONTROLE DE CONSTITUCIONALIDADE: MODELOS BRASILEIRO E ITALIANO (BREVE ANÁLISE COMPARATIVA)*
}

\author{
EDILSON PEREIRA NOBRE JÚNIOR**
}

I. Introdução - II. Supremacia constitucional e inconstitucionalidade III. Natureza do órgão controlador - IV. Competência para a atuação controladora - V. Modos de manifestação - VI. Atos impugnáveis VII. Parâmetros - VIII. Visão de confronto entre as decisões da Corte Constitucional e do STF - IX. Considerações finais.

\section{I - Introdução}

Uma das poucas premissas de constatação inabalável é a de que o direito, como instrumento retor da vida gregária, é um fenômeno universal, não podendo dele nenhuma comunidade prescindir.

A par disso, o entrelace entre os povos - cuja larga prática histórica vem, em tempos de globalização, alcançando frequiência cada vez mais crescente - tem mostrado a coincidência, em mais de um sistema jurídico, de princípios e institutos jurídicos semelhantes.

De logo se conclui que não se pode esquecer a importância do estudo do direito comparado, a qual, esvaindo-se bem mais além do deleite intelectual, desemboca,

* Exposição ministrada, no dia 09 de outubro de 2000, em seminário da disciplina Teoria do Direito Comparado, do Curso de Doutorado da Faculdade de Direito do Recife, cuja regência coube ao Prof. Ivo Dantas, titular de Direito Constitucional.

* Juiz Federal, Professor da UFRN, Professor de Especialização em Direito Administrativo da UFPE, mestre e doutorando pela Faculdade de Direito do Recife. 
como frisa IVO DANTAS, ' na finalidade profissional, afeiçoada à técnica e política jurídicas, ou mesmo política legislativa, no sentido de pôr à disposição dos operadores do direito, para uma melhor compreensão, os institutos existentes em outros ordenamentos, principalmente quando recepcionados pelo sistema nacional.

Nessa ordem de idéias, sobreleva notar a enorme relevância ostentada pela comparação na área do direito constitucional. Isso porque a sociedade hodierna é rotulada por um traço primordial, consistente na sua organização sob as vestes constitucionais. À sua Constituição, escrita ou não, compete, através de lineamentos gerais, não só proceder à estruturação dos poderes políticos, mas gizar os contornos da vida dos cidadãos, o que é realizado pela previsão dos chamados direitos de primeira (direitos individuais), segunda (direitos sociais), terceira (direitos à qualidade de vida, como a proteção do meio ambiente, ao consumidor etc.) e quarta (disciplina da pesquisa biológica e científica) gerações.

Apreendendo o valor da comparação no campo do direito constitucional, GIUSEPPE DE VERGOTTINI ${ }^{2}$ predica a ela múltiplas funções, sobressaindo-se as de: a) aquisição de novos conhecimentos indispensáveis para a compreensão do direito constitucional; b) elemento de controle para a verificação do fundamento dos conhecimentos pesquisados; c) servir de técnica de interpretação dos institutos constitucionais, principalmente quando realizada pelos órgãos jurisdicionais nacionais; d) auxílio na formulação das experiências normativas; e) cooperação na harmonização e unificação dos sistemas normativos.

Dito isso, não se deve perder de vista que da supremacia imanente às normas constitucionais, quando estas são dotadas de rigidez, segue-se o controle de constitucionalidade como meio indispensável para que se possa assegurar a permanência dos valores consagrados como fundamentais pela ordem jurídica. Essa a razão para a escolha do tema versado.

Nossa explanação, atenta aos imperativos da brevidade, pautar-se-á pela abordagem das semelhanças e distinções mais notáveis na tutela constitucional envidada pelos modelos nacional e italiano, tais como as inerentes à natureza e competência do órgão de controle, o modo de manifestação deste, tipos de ilegitimidade constitucional, os parâmetros de verificação, os atos impugnáveis e as singularidades das decisões. Antes do ingresso no objeto a ser analisado, não passarão despercebidos comentários sobre a noção de supremacia constitucional e a idéia de inconstitucionalidade.

1 Direito constitucional comparado : Introdução. Teoria e metodologia. Rio de Janeiro : Renovar, 2000. p. 62. Um pouco mais à frente (fls. 63), formula o autor duas advertências: a) não possui o direito comparado funçōes práticas, mas sim as conclusões dele resultantes, que terão valia para os legisladores, magistrados e advogados, a fim de propiciar uma melhor regulamentação do comportamento de uma determinada sociedade; b) a comum referência à universalização dos conceitos da ciência jurídica não deve implicar a crença de que se possa transportar um instituto de uma comunidade para outra, sem se levar em conta os condicionamentos e peculiaridades de cada uma delas.

2 Diritto costituzionale comparato. 4. ed. Padova : CEDAM, 1993. p. 5-30. 
A escolha do paradigma decorreu do fato de, malgrado integrante do conjunto de países pertencentes à denominada família romano-germânica, ou do civil law, o exemplo de fiscalização constitucional da Itália não mereceu maiores atenções dos estudiosos do assunto no Brasil.

\section{II - Supremacia constitucional e inconstitucionalidade}

Não constitui monopólio das duas últimas centúrias a aceitação da existência de normas de posição hierárquica diversa, umas servindo de fundamento de validade das demais. Para que não retroajamos demasiadamente no curso do tempo, pode-se dizer que, na Idade Média, SÃO TOMÁS DE AQUINO, principal representante da escolástica, salientava a presença da lei eterna, da lei natural e da lei humana, para sustentar que a obediência desta última somente estaria legitimada caso não contrariasse as duas primeiras.

Significa dizer, então, que a doutrina medieval pôs em relevo dicotomia entre duas classes de normas, quais sejam: o jus naturale, superior e incontrastável, e o jus positum, insuscetível de atritar-se com aquele.

Sem embargo, é no jusnaturalismo, iniciado a partir da segunda metade do século XVI, e amplamente divulgado no século XVIII, que surge, com maior nitidez e prestígio, a noção de Constituição.

Ressaibo embrionário dessa concepção está fincado em um dos documentos mais preciosos de nossa literatura constitucional, consistente em discurso proferido na instalação dos trabalhos da assembléia constituinte, que importou na promulgação da vigente Lei Maior, no qual JOSÉ CARLOS MOREIRA ALVES, então dignificando a presidência do Supremo Tribunal Federal, afirmava haver, na França do final do século XVI, cidadela inexpugnável do absolutismo, DE HARLAY sustentado a HENRIQUE III a distinção entre leis do rei e leis do reino, afirmando: "Temos, senhor, duas espécies de leis: umas são as ordenanças de nossos reis, que podem alterar-se conforme a diversidade dos tempos e dos negócios; outras são as ordenanças do reino, que são invioláveis, e pelas quais vós subsistes ao trono, e esta coroa foi conservada por vossos predecessores". 3

Tratava-se, ainda à época do ancien régime, de exemplo da manifestação dos parlamentos franceses, cuja funcionalidade se assemelhava à de uma corte de justiça, dirigida ao soberano, com o propósito de proceder ao exame dos editos régios ante as leis fundamentais do reino (lois fondamentalales du royaume).

Florescia, assim, o movimento contrário à monarquia absoluta, nascida em substituição ao feudalismo, modelo a notabilizar-se pela desmedida concentração de poderes em favor do monarca, o que, inexoravelmente, conduziu ao arbítrio.

No afã de combater esse estado de coisas, procurou-se a implantação de controle sobre o poder régio, a fundar-se na divisão das funções estatais, com o deslocamento

3 Assembléia Nacional Constituinte. Instalação. Revista de Informação Legislativa. a. 24, $\mathrm{n}^{\circ}$ 93, p. 5-14, jan./mar. 1987. 
do seu exercício do centro monopolizador existente, com a finalidade de preservação dos direitos fundamentais, calcados na igualdade e na liberdade do homem.

Para que tal conquista se vocacionasse à perenidade, concebeu-se, de logo, que não poderia ter as suas bases fincadas unicamente na lei, embora esta fosse apontada como a única forma de restrição da liberdade individual, ${ }^{4}$ simplesmente porque bastaria uma outra lei para que fosse extinta a separação de poderes e os direitos individuais oponíveis ao Estado.

Isso se justificava em face de que, na trilha do jusnaturalismo, a existência, em prol do ser humano, de direitos inatos, intangíveis e irrenunciáveis, pressupunha o estabelecimento de limites para o próprio legislador.

Essa idéia fora encampada por JOHN LOCKE, que, mesmo atuando como um dos mais ardorosos defensores da supremacia do Parlamento ante os demais poderes, não desconsiderava devesse aquele encontrar limites no direito natural. ${ }^{5}$ Reputandose que a função legislativa é deferida pelos cidadãos aos seus representantes, com vistas à realização de um determinado objetivo (que, no breviário liberal, era a proteção da liberdade e propriedade individual). segue-se que tal prerrogativa deverá retornar às mãos daqueles que a concederam, desde que os mandatários escolhidos desprezem ou contrariem flagrantemente a finalidade para cuja satisfação aquela fora concedida.

A saída, então, recaiu na inscrição da repartição de funções estatais, bem como dos direitos dos indivíduos, em uma norma de hierarquia superior à lei, que seria fruto de um poder soberano e criador do Estado. A tarefa caberia à Constituição, oriunda do poder constituinte, pertencente ao povo, e cujo fundamento reside no direito, conatural a cada comunidade, de escolher as instituições por que há de ser regida.

Está-se ante o que se convencionou denominar de supremacia constitucional, expressando que a Constituição, como pacto fundador da organização estatal, posiciona-se com superioridade diante das demais normas de determinado sistema positivo.

Essa qualidade constou de reconhecimento explícito no Artigo VI, inc. $2^{\circ}$, da Constituição dos Estados Unidos da América: "Esta Constituição, as leis dos Estados

4 Percebe-se do texto do art. $5^{\circ}$ da Declaração dos Direitos do Homem e do Cidadão, de 26 de agosto de 1789, a exaltação da lei como mecanismo hábil para a contenção de direitos e liberdades individuais.

5 É o que se infere de passagens de sua obra Segundo tratado sobre o governo, pois se é certo que afirmara que "enquanto subsiste o governo, o legislativo é o poder supremo; o que deve dar leis a outrem deve necessariamente ser-lhe superior" (Capítulo XIII, $\S 150$ ), não menos correto haver, no parágrafo antecedente, precatado a seguinte sentença: " Embora em uma comunidade constituída, erguida sobre a sua própria base e atuando de acordo com a sua própria natureza, isto é, agindo no sentido da preservação da comunidade, somente possa existir um poder supremo, que é o legislativo, ao qual tudo deve ficar subordinado, contudo, sendo o legislativo somente um poder fiduciário destinado a entrar em ação para certos fins, cabe ainda ao povo um poder supremo para afastar ou alterar o legislativo quando é levado a verificar que age contrariamente ao encargo que lhe confiaram" (Capítulo XIII. \$ 149). 
Unidos em sua execução e os tratados celebrados, ou que houverem de ser celebrados em nome dos Estados Unidos, constituirão o direito supremo do país. Os juízes de todos os Estados dever-lhes-ão obediência, ainda que a Constituição ou as leis de algum Estado disponham em contrário".

Todavia, é de salientar que a concreção da cláusula demorou aproximadamente mais uma década e meia. Coube à Suprema Corte norte-americana, no julgamento do famoso caso Marbury v. Madison (1 Cranch 137), fincar, no ano de $1803,{ }^{6}$ através do labor do Juiz JOHN MARSHALL, o ponto de vista de que uma lei do Congresso, quando contrária à Constituição, carece de validade.

Tratava-se de mandamus, impetrado originariamente perante o Tribunal Supremo, em virtude de competência deferida pela Lei do Poder Judicial de 1789. MARSHALL partiu do pressuposto de que a jurisdição da Suprema Corte era exercida originariamente, ou em grau de recurso, sendo a primeira hipótese de enunciação constitucional. Em vista disso, com base na impossibilidade de o legislador, pena de enfrentar o Texto Magno, ampliar o rol da competência originária da Suprema Corte, votou pela incompetência do tribunal para o conhecimento do pedido. Em conclusão, assentara que se uma lei ingressa em contenda com a Constituição, indiscutível o seu caráter de lei inconstitucional, não merecendo, por isso, ser observada.

A invalidade, portando, da lei violadora da Constituição é uma decorrência da posição superior em que esta se encontra. Essa superioridade se faz presente nos países que abraçam a rigidez constitucional, onde, explanou OSWALDO ARANHA BANDEIRA DE MELLO, em obra pioneira na literatura jurídica pátria, nos países que abraçam a rigidez constitucional, " a Constituição é a autoridade mais alta, $e$ derivante de um poder superior à legislatura, o qual é o único poder competente para alterá-la. O poder legislativo, como os outros poderes, the são subalternos, tendo as suas fronteiras demarcadas por ele, e, por isso, não podem agir senão dentro destas normas".?

\section{III - Natureza do órgão controlador}

O primeiro aspecto a servir de confronto é o inerente às características ostentadas pelo órgão, ou órgãos, com competência para zelar pelo respeito à lei fundamental.

6 Informa CHRISTOPHER WOLFE (La transformacion de la interpretacion constitucional. Madri : Civitas, 1991.p.115) que, com exatidão, o controle de constitucionalidade por juizes federais fora exercitado pela primeira vez nos anos da década de 1790, nos quais vários presidentes de tribunais de circuito se negaram a reconhecer a vigência de uma lei que àqueles impuseram obrigaçōes não judiciais, sem contar que a Suprema Corte, no ano de 1795 (Hylton v. united States, 3 Dallas 171), examinara lei tributária federal ante a Constituição, muito embora tenha concluído pela valência do imposto discutido.

7 Teoria das constituiçōes rígidas. 2. ed. São Paulo : José Bushatsky Editor, 1980. p. 48. 
Grosso modo, podemos agrupar de duas formas principais as maneiras pelas quais as constituições hodiernas atribuem a missão de conhecer de pleitos inerentes à violação de suas normas.

Assim, tem-se, inicialmente, o controle exercitado por órgãos políticos, podendo recair no próprio Poder Legislativo. Como exemplos pode ser apontado o Conselho Constitucional da atual Constituição Francesa (arts. 56 a 63) e o Presidium do Soviete Supremo da Constituição da extinta União das Repúblicas Socialistas Soviéticas de 07/10/77 (art. $121^{\circ}, n^{\circ} 4$ ), a Comissão Constitucional e Jurídica da Constituição romena de 20/08/65 (art. 53), com as revisões de 27/12/74 e de 18/03/75, e a Comissão Constitucional da Constituição tchecoslovaca de 11/07/60 (arts. 87, 88, 90 a 92), com as alterações da Lei Constitucional de 20/12/70.

A escolha de tal via decorre da opinião de que, resultando a lei da manifestação de órgão representativo da soberania popular, não seria de bom grado que os seus atos estivessem submetidos à viligância por outro poder, como é o caso do Judiciário.

Isso é bem explicado por BISCARETTI DI RUFFIA quando afirma que a utilização, para fins de fiscalização constitucional, dos próprios órgãos legislativos, fora sugerida "pela convicção da oportunidade de atribuir aos órgãos mais representativos da vontade popular algumas funçōes jurisdicionais, de notável relevo, nas quais aparece particularmente avaliável o elemento político" 8

Outro modelo, cujo berço fora o judicial review do direito norte-americano, confere a organismo do Poder Judiciário a missão de declarar a invalidade das leis, e outros atos estatais, infringentes da Lei Maior, tendência que vem se acentuando, cada vez mais, a partir da Primeira Conflagração Mundial.

O Constituinte de 1988, mantendo tradição inaugurada com a Constituição de 1981, optou por outorgar aos tribunais o reconhecimento da incompatibilidade dos atos normativos ante a Lei Básica, segundo se depreende da redação do art. 97: "Somente pelo voto da maioria absoluta de seus membros ou dos membros do respectivo órgão especial poderāo os tribunais declarar a inconstitucionalidade de lei ou ato normativo do Poder Público".

O dispositivo, complementado pelos arts. 102, I, letras $a$ e $q, \S 1^{\circ}, 103, \S 2^{\circ}$, 105 , letra $h$, todos da Constituição Federal, não exclui a atuação do Executivo e do Legislativo na fiscalização constitucional, ${ }^{9}$ o que se dá durante o processo de formação das leis, através do veto (art. $66, \S 1^{\circ}, C F$ ), e das decisões de admissibilidade proferidas pelas comissões parlamentares, nos termos dos regimentos internos das casas legislativas.

8 “dalla convinzione dell'opportunità d'attribuire agli organi più rappresentativi della volontà popolare alcune funzioni giurisdizionali, di notevole relevo, in cui apparisse particolarmente valutabile l'elemento politico". (RUFFIA, Paolo Biscaretti Di. Diritto costituzionale. 15. ed. Napoli : Jovene, 1989. p. 643).

9 Acerca do assunto, consultar GILMAR FERREIRA MENDES (O Poder Executivo e o Poder Legislativo no controle de constitucionalidade. Revista de Informação Legislativa, Brasília, a. 34 , n. 134, p. 11-39, abr./jun. 1997). 
Não esquecer ainda a competência que a Constituição, no seu art. 49, V, outorgou ao Congresso Nacional, a fim de sustar os atos normativos do Poder Executivo que exorbitem do poder regulamentar (regulamentos), ou dos limites de eventual delegação legislativa (lei delegada). Ao contrário das situações referidas no parágrafo anterior, trata-se de atuação parlamentar, levada a cabo em instante posterior à perfeição do ato questionado. ${ }^{10}$

Passando-se ao arquétipo constitucional italiano, moldado pela Constituição de 23 de dezembro de 1947, tem-se, nos termos do seu art. 134, a atribuição à Corte Constitucional das controvérsias relativas à legitimidade constitucional dos atos normativos do Estado e das Regiões.

Superados, nos trabalhos preparatórios da referida Lei Fundamental, os pontos de vista que apregoavam a necessidade de que tal controle fosse realizado por órgão político, ou que competisse a cada um dos juízes, no âmbito de suas competências, prevaleceu a criação de um órgão novo, com o propósito de canalizar as contendas que envolvessem a incidência da Constituição.

Embora a ausência de menção à Corte Constitucional no Título $\mathrm{V}$ da Constituição italiana, possa haver servido para que se pudesse sustentar a condição de órgão político daquela, a doutrina vem convergindo à sua qualificação como organismo jurisdicional, embora dotado de traços peculiares. Dentre alguns autores, essa é a opinião sustentada por LIVIO PALADIN ${ }^{1}$, a qual se encontra ratificada em obra escrita com a colaboração de VEZIO CRISAFULLI ${ }^{12}$, GIUSEPPE DI VERGOTTI$\mathrm{NI}^{13}$, FAUSTO CUOCULO ${ }^{14}$, ROBERTO BIN ${ }^{15}$ e GONZALEZ RIVAS ${ }^{16}$.

10 Sem embargo de não poder o Executivo declarar inconstitucional uma regra de direito, tem-se reconhecido, tanto à época da Lei Maior pretérita (STF. Pleno, mv, Rep. 980-SP, rel. Min. MOREIRA ALVES, RTJ 96/496, encontrando-se no voto-condutor menção a vários precedentes no mesmo sentido) quando da atual (STF, Pleno, ac. un., ADINMC 1.292 - MT, rel. Min. ILMAR GALVÃO, DJU de 15/09/95, pág. 29.508), a possibilidade de a chefia daquele determinar aos órgãos que lhe são subordinados que deixem de aplicar leis, ou atos com força de lei, que reputem inconstitucionais, entendimento aplicável ao Legislativo e ao Judiciário quando no exercício do desempenho de função administrativa.

11 Diritto costituzionale. 2. ed. Padova : CEDAM, 1995. p. 705.

12 Commentario breve alla costituzione. Padova : CEDAM, 1990. p. 796.

13 Diritto costituzionale. Padova : CEDAM, 1997. p. 618.

14 Principi di diritto costituzionale. Milano : Giuffrè, 1996. p. 731 e seguintes. O pensamento do autor assoma, com maior clareza, às fls. 741 da obra referenciada, quando afirma: "Como dito, a Corte constitucional no nosso ordenamento é órgão de garantia e, enquanto tal, exercita um controle, de forma jurisdicional, sobre alguns atos do Estado e das regiões e julga sobre os comportamentos, penalmente relevantes, do presidente da República, nos limites estabelecidos pela Constituição". "Como si è detto, la Corte costituzionale nel nostro ordinamento è organo de garanzia e, in quanto tale, esercita un controlo, in forma giurisdizionale, su taluni atti dello Stato e delle regioni e giudica sui comportamenti, penalmente rilevanti, del presidente della Republica, nei limiti stabiliti dalla Costituzione".

15 Capire la costituzione. Roma : Editori La perza, 1998. p. 7.

16 La justicia constitucional: derecho comparado y español. Madrid : Editoriales de Derecho Reunidas, 1985. p. 59. O autor, mesmo notando que a Corte Constitucional italiana não está 
O próprio Diploma Básico italiano nos oferta tal conclusão, conforme se infere do emprego das seguintes expressões: a) giudica (julga), no seu art. 134, caput; b) giudici (juízes), nos arts. 135, $\mathrm{n}^{\circ} \mathrm{s} 1$ a 3 e 7 , e 137, $\mathrm{n}^{\circ} 1$; c) giudice (juiz), no art. $135, \mathrm{n}^{\circ} \mathrm{s} .4$ e 6 ; d) giudizi (juízos, podendo também ser traduzida como julgamentos), nos arts. $135, \mathrm{n}^{\circ} 7$, e $137, \mathrm{n}^{\circ} 1$.

Além disso, reforça o caráter judicial das funções da Corte Constitucional o fato de os seus membros estarem sujeitos a uma série de incompatibilidades e garantias, necessárias para a preservação de sua independência funcional.

De logo, tem-se, de acordo com o art. $135, \mathrm{n}^{\circ} 5$, da Lei Fundamental itálica, que a função de juiz constitucional é incompatível com a de parlamentar, de membro de Conselho Regional, com o exercício da atividade de advogado, bem como com qualquer outro cargo ou função indicados em lei. Vale notar que a Lei 87, de 11 de março de 1953 , acrescentou, nos seus arts. $7^{\circ}$ e $8^{\circ}$, as proibições derivadas do exercício das atividades de comerciante, ou industrial, de qualquer função ou emprego, público ou privado, ou quanto ao desenvolvimento de atividades em associações ou partidos políticos.

Doutro lado, na forma da Lei Constitucional $n^{\circ} 1$, de 09 de fevereiro de 1948, com as alterações da Lei Constitucional $n^{\circ} 1$, de 11 de março de 1953, os juízes da Corte Constitucional são invioláveis pelas opiniões contidas nos votos, proferidos no desempenho de suas funções, juntamente com a extensão da imunidade, de cunho processual e ante a prisão, conferida pelo art. $68, n^{\circ} 2$, da Constituição, aos parlamentares.

De destacar que os diplomas legais citados garantem a impossibilidade de os juízes, no curso do seu mandato, serem removidos, ou suspensos de suas atividades, salvo as hipóteses de incapacidade física ou civil superveniente, ou do cometimento de graves faltas durante o desempenho do mister, a serem apreciadas pela Corte Constitucional, mediante a maioria de dois terços.

A despeito do caráter jurisdicional, ostentado pela Corte Constitucional da Itália, não se pode negar a existência de características especiais desta, não ocorrentes na organização judiciária brasileira. Tais singularidades, que motivaram a qualificação, por BISCARETTI DI RUFFIA, ${ }^{17}$ da Corte Constitucional itálica como orgão constitucional, de natureza jurídico-política, consistem na: a) temporariedade do exercício do munus judicante que, segundo o art. 135, n 3, da Lei Maior de 1947, não poderá ultrapassar nove anos, contados do dia em que tomado o compromisso, sendo incabível nova designação, ao passo que, tanto no Supremo Tribunal Federal, quanto nos demais juízos e tribunais brasileiros, a investidura se vocaciona à vitaliciedade; b) nomeação dos seus membros pelo Presidente da República, pelo Parlamento, em sessão comum, e pelas supremas magistraturas ordinária e administrativa, à proporção de um terço cada qual (art. $135, \mathrm{n}^{\circ} 1$ ), ${ }^{18}$ enquanto os ministros do Supremo

compreendida na parte referente ao Judiciário, enfatiza que aqueia desenvolve funções materialmente jurisdicionais, ao exercer o controle da constitucionalidade normativa.

17 Diritto costituzionale. 15. ed. Napoli : Jovene, 1989. p. 647.

18 Daí que, dos quinzes juízes da Corte Constitucional, cinco são escolhidos pelo Presidente da 
Tribunal Federal são, sem exceção, nomeados pelo Presidente da República, malgrado tal escolha depender de prévia aprovação de uma das casas do Congresso Nacional, qual seja o Senado Federal (art. 101, parágrafo único, CF).

É preciso atentar que, embora na Itália a apreciação da alegação de inconstitucionalidade de atos normativos pertencer à Corte Constitucional, tal exclusividade se manifesta quando já perfeita a lei, ou ato com força de lei, suscetível de impugnação.

Por essa razão, lembra-nos GIUSEPPE DE VERGOTTINI, ${ }^{19}$ ser preciso observar que, durante o iter de conversão em lei de um decreto-legge, prevêem os regulamentos parlamentares (art. 96, Regulamento da Câmara; art. 78, Regulamento do Senado) controle político, voltado à presença dos pressupostos constitucionais de necessidade e urgência, a ser desenvolvido por comissões. Caso haja conclusão pela não admissibilidade, a matéria tocará ser apreciada, em via prejudicial, pelo plenário da respectiva casa.

Da mesma maneira, o art. $127, n^{\circ}$ s $3^{\circ}$ e $4^{\circ}$, do Texto Supremo italiano, prevê, quando da estimativa de que lei regional colida com os interesses nacionais, ou de outras Regiões, a possibilidade de recurso do Estado perante as Câmaras. Isso somente terá lugar quando, a pedido do governo da República, o Conselho Regional voltar a aprová-la por maioria absoluta dos seus membros.

O Executivo, quer o Presidente da República, quer o Governo (Conselho de Ministros), não dispõe de qualquer prerrogativa, no intuito de obstar a transformação em lei de projeto que apresente alguma mácula de inconstitucionalidade, uma vez que, ao contrário das constituições dos países presidencialistas, como a brasileira, aquele não dispõe da prerrogativa de veto, substituído pelo potere di rinvio, previsto no art. 74 da Lei Fundamental de 1947.

\section{IV - Competência para a atuação controladora}

Ficou assentado que, tanto no Brasil como na Itália, a guarda da autoridade do Estatuto Supremo compete, primacialmente, a órgãos jurisdicionais, sendo escassas

República (sem anteceder proposta do Governo, de modo a que tais nomeações sejam subtraídas da ingerência política), cinco pelo Parlamento (o que é feito mediante maioria qualificada, com o propósito de evitar vinculação particular do eleito com determinado bloco político) e cinco pelas supremas magistraturas. cabendo três vagas à Corte de Cassação (suprema magistratura ordinária), uma ao Conselho de Estado (suprema magistratura administrativa) e, por último, uma à Corte de Contas (suprema magistratura em matéria de contabilidade pública). A designação deverá recair entre magistrados, conquanto aposentados, das jurisdições superiores ordinária e administrativa, professores universitários de matérias jurídicas e advogados, estes desde que contêm com mais de vinte anos de profissão (art. $135, \mathrm{n}^{\circ} 3$ ). Nos julgamentos de acusação promovida contra o Presidente da República e os membros do Governo, a Corte terá a sua composição acrescida de dezesseis cidadãos, sorteados dentre os integrantes de lista formada pelo Parlamento no início de cada legislatura e que preencham os requisitos de elegibilidade para senador.

19 Diritto costituzionale. Padova : CEDAM, 1997. p. 622. 
as situações de controle político. Resta agora indagar se, em ambos os sistemas jurídicos, podem os diversos órgãos judiciais, cada qual no âmbito de sua competência, conhecer e decidir questões que envolvam a suscitação de inconstitucionalidade de lei ou ato normativo, muito embora tais decisões não sejam capazes de produzir o alijamento da norma do ordenamento.

Sob essa ótica, tem-se a linha divisória entre os chamados modelos concentrado e difuso. O primeiro, de maior frequêencia no continente europeu, onde tiveram início com a Constituição Austríaca de 1920, reservam a um único órgão, normalmente denominado como corte ou tribunal constitucional (o qual poderá coincidir com o órgão jurisdicional de maior hierarquia, ou em organismo especialmente criado para esse fim), a tarefa de sindicar as ofensas à supremacia constitucional. Funda-se no objetivo de se alcançar a certeza do direito, a qual ficaria imposta a contrastes ante a flutuação jurisprudencial, resultante do entendimento de vários juízes.

Em contraposição, há o modelo difuso, protagonizado nos Estados Unidos da América, onde os julgamentos sobre a legitimidade constitucional são considerados como um reflexo da função jurisdicional, sendo atribuídos a todos os juízes indistintamente. A sua inspiração parece recair nas extremas consequiências, a serem conferidas à supremacia constitucional, implicando na imediata inobservância das leis e regulamentos contrários à Lex Mater.

O sistema jurídico nacional, filiado ao modelo difuso desde a Constituição de 1891, em face da influência americana que, na sua elaboração, recebera por intermédio de RUI BARBOSA, passou, com a Emenda Constitucional 16/65 à Constituição de 1946, criadora da saudosa representação de inconstitucionalidade, a ostentar natureza eclética.

Daí competir a todos os juízos, singulares ou colegiados, na solução dos casos concretos que lhes são submetidos, conhecer de questionamentos inerentes à contrariedade entre uma lei, ou um regulamento, ante a Constituição, tendo como consequêencia, na hipótese do reconhecimento do vício apontado, a não aplicação da norma impugnada, a qual continuará integrando o sistema.

A despeito disso, a Constituição de 1988 prevê o controle mediante o ajuizamento de ação direta de inconstitucionalidade, cujo conhecimento é exclusivo do Supremo Tribunal Federal, podendo resultar, em havendo a procedência do seu pedido, na perda de eficácia da norma combatida, com a sua retirada do sistema. Em outras situações, a Constituição também reserva o conflito constitucional ao descortino único do Supremo Tribunal Federal. São elas: a) a ação declaratória de constitucionalidade, ajuizada com o propósito de afastar dúvidas quanto à validade de lei ou ato normativo federal (art. 102, I, $a, \S 2^{\circ}, \mathrm{CF}$ ); b) o mandado de injunção, nas hipóteses do art. 102, I, $q$, da CF; c) a arguiição de descumprimento de preceito fundamental (art. 102, $\S 1^{\circ}, \mathrm{CF}$ ), atualmente regulamentada pela Lei 9.882 , de $03 / 12 / 99$; d) a ação de inconstitucionalidade por omissão (art. 103, $\S 2^{\circ}, C F$ ).

Diferentemente, no sistema jurídico peninsular, conforme decorre do dito contido no art. 101, segunda parte, da Constituição de 1947, os magistrados estão sujeitos somente à lei. Ainda que se possa, com certa dose de acerto, sustentar que a Constituição é uma lei, sendo inclusive a de maior grau hierárquico, o juiz se encontra 
adstrito a fazer aplicação da legislação ordinária. Na hipótese do julgador vislumbrar contraste entre esta e a ordem constitucional, jamais poderá deixar de pôr em prática a primeira, substituindo-a pela segunda. Se entende insuperável a antinomia, deverá suspender o feito, submetendo a questão à Corte Constitucional.

Para ser mais exato, como o faz ROBERTO BIN, "é somente a Corte constitucional que pode declarar a ilegitimidade constitucional de uma lei, eliminando-a do ordenamento: os juizes não podem fazer outra coisa que manifestar a sua dúvida, a qual será pela Corte desatada, resolvendo a antinomia". ${ }^{20}$

Esse rigorismo não quer dizer seja impossível ao julgador ordinário ou administrativo, na sua faina de compor litígios, adequar, através do esforço hermenêutico, o texto legal à Constituição, solucionando contradição aparente. Interessante o exemplo mencionado pelo próprio ROBERTO BIN ${ }^{21}$, noticiando que um jovem professor de ginástica, dispensado de seus serviços em escola católica, em virtude de haver contraído núpcias pelo rito civil, resolvera impugnar a sua dispensa, havendo o caso sido levado até a Corte de Cassação, a qual lhe deu razão.

Para assim concluir, encontrava-se o Tribunal ante obstáculo posto em lei ordinária, a qual permitia às organizações de tendência (escolas confessionais, movimentos políticos, jornais de partidos etc.) dispensar os seus empregados que tivessem comportamentos incompatíveis com a ideologia professada pela instituição. A saída foi utilizar a Constituição, a qual protege, às expressas, o direito ao trabalho (art. $4^{\circ}$ ), entendendo a Corte que os atos da vida privada de um professor, cuja atividade é o ensino de ginástica, não eram capazes de incidir sobre a linha ideológica do ensino da organização, a fim de respaldar uma lesão assim tão drástica ao direito ao labor.

Nada mais fez a Corte de Cassação senão interpretar a lei em causa de maneira a que pudesse se conformar à Lei Maior, procedendo, de consequiência, à anulação do ato de dispensa. Caso o dispositivo legal não permitisse uma adequação interpretativa, capaz de torná-la compatível com a Constituição. outra saída não teria a jurisdição ordinária a não ser submeter à Corte Constitucional a questão, com vistas a que esta declarasse a ilegitimidade da norma legal.

A título de curiosidade, diga-se que, durante breve período depois de vigente a Constituição de 1947, o controle de constitucionalidade na Itália ainda permanecera submetido à jurisdição difusa. É que o item VII, Segunda parte, das disposições transitórias e finais, prescrevia que, enquanto não entrasse a Corte Constitucional em funcionamento, as decisões sobre as controvérsias indicadas no art. 134 da Lei Maior teriam lugar nas mesmas formas e limites pré-existentes à entrada em vigor da Constituição. Somente em 23 de abril de 1956, ou seja, aproximadamente oito

20 "' è solo la Corte costituzionale che può dichiarate l'ilegittimità costituzionale di una legge, eliminandola dall' ordinamento: i giudici non possono far altro che manifestare il loro dubbio, che sarà la Corte a sciogliere, risolvendo l'antinomia". (Capire la costituzione. Roma : Editori La perza, 1998. p. 8).

21 ibidem, p. 6-7. 
anos após, é que a Corte Constitucional realizara a sua primeira audiência. Nesse interim, ocorreram a promulgação das Leis Constitucionais 01/1948 e 01/1953, e da Lei $87 / 1953$, juntamente com a escolha e designação dos juízes. ${ }^{22}$

\section{$\mathrm{V}$ - Modos de manifestação}

Duas são as formas principais, em face das quais se realiza o controle de constitucionalidade mediante a provocação da jurisdição. A primeira delas é a denominada incidental, exercitada durante o tramitar de um caso concreto, onde a argüição de legitimidade constitucional é assestada como prejudicial ao julgamento da causa.

Nessa modalidade, também conhecida como fiscalização por via de exceção, não há insurgência contra o ato normativo, indigitado como violador da Lei Básica, mas, no exato dizer de C. A. LÚCIO BITTENCOURT, "o lesado, em vez de atacar o ato diretamente, limita-se a se defender contra êle, se a autoridade tenta submetê-lo à sua aplicação". ${ }^{23}$

A diferença entre as ordens nacional e itálica reside aqui em um ponto fundamental. No direito brasileiro, compete às partes, aos terceiros (assistentes, opoentes etc.), ou ainda ao Ministério Público, suscitar a incompatibilidade vertical de uma norma inferior, em torno da qual gravita a pretensão ou sua resistência, ante o ordenamento magno, devendo a decisão ser proferida pelo juízo ao qual está afeto o processo.

A sistemática italiana, traçada pela Lei Constitucional $n^{\circ} 01 / 48$, dispõe, no seu art. $1^{\circ}$. que qualquer das partes, ou o juiz (ordinário ou administrativo), poderá, no curso de uma causa, trazer a lume indagação da legitimidade constitucional de uma lei, ou ato com força de lei, tendo a Lei $87 / 53$ estendido tal iniciativa ao Ministério Público.

No entanto, a decisão da questão suscitada não tocará ao magistrado que dirige o processo. Caberá a este, caso, após os debates de praxe, entenda relevante a discussão, submetê-la à Corte Constitucional em autos próprios (autos de remissão), suspendendo o andamento do processo sob sua direção.

Para tanto, exige-se alguns requisitos, quais sejam: a) a relevância do tema enfocado para o desenlace do litígio; b) não se apresentar manifestamente infundada a argüição, porquanto não se justifica a provocação da Corte Constitucional quando a lei em tela se revela, de maneira indiscutível, em compasso com a Lei Mor; c) haver, de acordo com o art. $1^{\circ}$ da Lei $01 / 48$, ratificado pelo art. 23 da Lei 87/53, a

22 Nesse curto espaço de tempo, funcionou, criada pelo art. 24 do Estatuto da Região da Sicília, a Alta Corte de Justiça siciliana, com a atribuição de controlar a validade das leis emanadas da Assembléia Regional.

23 O controle jurisdicional da constitucionalidade das leis. Brasília : Ministério da Justiça, 1987. p. 97. 
impugnação tido lugar "nel corso di un giudizio" (no curso de um juízo) e diante de uma "autorità giurisdizionale" (autoridade jurisdicional). ${ }^{24}$

Vê-se, portanto, que, enquanto no Brasil o controle incidental, ou por via de ação, é da alçada do juiz competente para o processo, no qual fora suscitado, ou seja, a sua apreciação se dá perante jurisdição difusa; na Itália, tal ocorre apenas quando de sua instauração, porquanto, quando da análise do mérito da questão, vem à ribalta concentração de competência em prol da Corte Constitucional.

Nota-se, doutro lado, convergência quanto à possibilidade, reconhecida às expressas pelo art. $1^{\circ}$ da Lei Constitucional de 01/48, bem como pela doutrina patrial, ${ }^{25}$ no sentido de permitir ao juiz, conforme a situação, suscitar a dúvida de constitucionalidade, ou reconhecê-la, sponte propria, sem depender da iniciativa de qualquer das partes, ou do Ministério Público.

Resta analisar o controle dito principal, ou por via de ação, consistente em um processo instaurado diretamente contra o ato apontado como inconstitucional (lei ou ato normativo). Afasta-se do incidental, principalmente em face de: a) sua natureza abstrata, dispensando qualquer problema de aplicação, perante casos concretos, da disposição atacada; b) corresponder, acima de tudo, à função de garantia da higidez do texto constitucional.

Passaremos a analisar os protótipos brasileiro e italiano, conforme vários aspectos, concernentes à origem dos atos impugnados, à legitimação ativa, aos tipos de feitos, à caducidade, à existência de partes, à possibilidade de cautelar, à admissibilidade da inconstitucionalidade por omissão e ao quorum necessário à declaração de inconstitucionalidade.

Quanto à origem das normas contestadas, a diferença resulta da forma em que organizados os estados brasileiro e italiano. Enquanto entre nós é possível o ataque,

24 Sobre esse aspecto, comentam CRISAFULLI \& PALADIN (Commentario breve alla costituzione. Padova : CEDAM, 1990. p. 781) orientar-se a Corte Constitucional mediante critérios ampliativos, de maneira a compreender sob a expressão giudizio não somente os feitos contenciosos, abrangendo também os procedimentos de jurisdiçāo voluntária, haja vista que a instauração da fiscalização constitucional não pressupõe um conflito entre partes, em torno da incidência da norma impugnada, mas a necessidade de se alcançar uma certeza jurídica, abalada pela dúvida de inconstitucionalidade (sentenze 129/1957, 142/1971 e 17/1980). Na mesma linha, a Corte reputou autorità giurisdizionale órgãos que, a despeito de estranhos à organização da justiça, estão, excepcionalmente, investidos em funções judicantes, para fins de aplicação da lei, encontrando-se em posição eqüidistante das partes. Assim, foram admitidas contestações provenientes: a) dos conselhos comunais e provinciais, em sede de contencioso eleitoral (sentenze 41 a 44/1961, 92/1962, 93/1965, 58/1966 e 19/1967); b) do Conselho Nacional Forense, no que concerne às decisões em matéria de recursos, dirigidos contra os procedimentos adotados nos conselhos singulares (sentenza 114/1970); c) da Seção Disciplinar do C.S.M. (sentenze 12/1971. 145/1976 e 69/1977); d) da Corte de Contas (sentenze 54/1975, 164/1982); e) do Comissário Liquidador dos Usos Civis (78/1961).

25 C.A. LÚCIO BITTENCOURT ( $O$ controle jurisdicional da constitucionalidade das leis. Brasília: Ministério da Justiça, 1987. p. 113); NAGIB SLAIBI FILHO (Anotaçōes à constituição de 1988; aspectos fundamentais. Rio de Janeiro: Forense, 1989. p. 87); CLĖMERSON MERLIN CLĖVE (A fiscalização abstrata de constitucionalidade no direito brasileiro. São Paulo : Revista dos Tribunais, 1995. p. 79). 
mediante ação direta de inconstitucionalidade, de atos normativos federais, estaduais e, em situações especiais, também municipais ${ }^{26}$, a Constituição italiana (art. 134, I) restringe a competência da Corte Constitucional à apreciação dos vícios de legitimidade das leis do Estado (ou da República) e das Regiões.

A circunstância de, apesar da estrutura territorial itálica compreender também Províncias e Municípios, não haver necessidade da aferição da compatibilidade das leis destas, em face da Constituição do Estado, tributa-se ao fato de as suas competências não encontrarem delimitação em sede de Lei Maior, o que lhes garantiria autonomia política, constando, ao invés, de leis gerais da República (art. 128).

A legitimidade ativa também é diferente. No Brasil, a qualidade para o ajuizamento das diversas demandas diretas, consagradas pela Constituição Federal, está repartida conforme se trate de: a) ação direta de inconstitucionalidade, incluindo a destinada a sanar omissão (art. 103, I a IX, CF) ${ }^{27}$; b) ação declaratória de constitucionalidade (art. 103, $\left.\S 4^{\mathbf{0}}, \mathrm{CF}\right)^{\mathbf{2 s}}$; c) argüição de descumprimento de preceito fundamental, cabendo a aplicação, nos termos do art. $2^{\circ}$, I, da Lei $9.882 / 99$, do art. 103, I a IX, da CF; d) ação direta interventiva (art. 36, III, CF), cuja titularidade exclusiva de sua provocação cabe ao Procurador-Geral da República.

No sistema peninsular, o recurso, ativador da via principal, somente poderá ser promovido pelo Estado (tocando a sua representação ao Governo, sendo indispensável, a teor dos arts. 30 e 31 da Lei 87/53, prévia deliberação favorável do Conselho de Ministros, tanto que a Corte Constitucional, na sentenza 116/1966, somente admitira a iniciativa isolada do seu Presidente, mesmo em caso de urgência, com a posterior ratificação do Conselho de Ministros), pelas Regiões (sendo necessária a autorização da Junta Regional), pelas Províncias de Trento e Bolzano e, finalmente, por grupos lingüísticos, com restrição, nesta última hipótese, às leis aprovadas pelas Regiões e pela Província de Bolzano. ${ }^{29}$

A Lei Fundamental de 1988, ao contrário da anterior, que se limitava a contemplar a representação de inconstitucionalidade e a interventiva, criou vários mecanismos idôneos a provocar o controle por via de ação, sendo eles a ação declaratória de inconstitucionalidade (por ação e omissão), a ação direta interventiva ${ }^{30}$, a ação

26 Consultar recente decisão no RE 213.120 - 2 - BA ( $2^{\mathrm{a}}$ T., ac. un., rel. Min. MAURíCIO CORRĖA, DJU de 02/06/2000) que, alinhada à jurisprudência dominante, concebe o ajuizamento de ação direta perante o STF quando a lei municipal é arrostada com base em preceitos da Constituição Federal, não reproduzidos pela do Estado-Membro.

27 Dispõe o referido dispositivo: "Art. 103. Podem propor a ą̧ão direta de inconstitucionalidade: I-o Presidente da República: II - a Mesa do Senado Federal: III - a Mesa da Câmara dos Deputados: IV - a Mesa da Assembléia Legislativa: V - o Governador do Estado: VI - o Procurador-Geral da República: VII - o Conselho Federal da Ordem dos Advogados do Brasil; VIII - partido político com representação no Congresso Nacional: IX - confederação sindical ou entidade de classe de âmbito nacional".

28 Aqui circunscreveu-se a legitimação ao Presidente da República, Mesas do Senado Federal e da Câmara dos Deputados e Procurador-Geral da República.

29 O Estatuto Trentino-Alto-Adige exclui dos grupos lingüísticos a legitimidade para questionar as leis da Província de Trento. 
declaratória de constitucionalidade (criação, a nosso ver desnecessária, da EC 03/93, bastando que a construção jurisprudencial legasse à ação direta de inconstitucionalidade, quando da rejeição do seu pedido, o mesmo efeito a ser almejado com a iniciativa do constituinte reformador) e a argüição de descumprimento de preceito fundamental. Mais simples, o direito italiano contenta-se, no particular, com a figura do recurso à Corte Constitucional.

Diversamente do praticado nestas plagas, onde prevalece o entendimento de que a inconstitucionalidade pode ser declarada qualquer que seja o tempo de vigência da lei a ser atacada, o mesmo não acontece no regime italiano. Neste, com exceção da fiscalização incidental, a qual cabe ser encetada a qualquer tempo, possui o Estado prazo, que entendo melhor denominá-lo de caducidade ou decadência, para impugnar as leis regionais, mediante recurso direto à Corte Constitucional. É de quinze dias, contados da data em que, na forma do art. $127, n^{\circ} 4$, da Constituição, o Presidente do Conselho de Ministros receber a comunicação do Presidente da Junta Regional, noticiando que a lei em tela fora, ao ser novamente submetida ao beneplácito do Conselho Regional, aprovada com a maioria absoluta de seus integrantes.

Quanto aos recursos regionais, a serem interpostos contra leis do Estado ou de outras Regiões, o prazo decadencial será, respectivamente, de trinta a sessenta dias, cujo termo a quo será o da respectiva publicação oficial, conforme os arts. 32 e 33, da Lei $87 / 53$.

Outra distinção recai no caráter objetivo, que se costuma irrogar ao controle principal, ou por via de ação, de sorte a se manifestar mediante processos sem sujeitos, cujo objetivo precípuo é a guarda da Constituição. Seguindo essa linha, o Supremo Tribunal Federal, desde a época da já vetusta representação de inconstitucionalidade, entendeu ser inconcebível a desistência, ${ }^{31}$ posicionamento mantido a partir da atual ordem sobranceira, ${ }^{32}$ tendo inclusive merecido consagração legislativa (art. $5^{\circ}$, caput, Lei 9.868, de 10/11/99). Informada pelo mesmo fundamento, restou vedada também a possibilidade de intervenção de terceiros (art. $7^{\circ}$, caput, da Lei 9.868/99). ${ }^{33}$

$\mathrm{Na}$ Itália, o controle principal, como bem enfocam CRISAFULLI \& PALADIN, ${ }^{34}$ é estruturado como processo de partes, tanto por concernir ao recorrente delimitar a matéria da contenda quanto pela faculdade daquele em desistir do prosseguimento da controvérsia, o que denota o seu caráter disponível.

30 O Constituinte de 1988 , persistindo em equívoco, ainda menciona o vocábulo "representação" no art. 36 , III, de sua obra.

31 RTJ 23/1.

32 Pleno, ADIN 164 - DF, ac. un., rel. Min. MOREIRA ALVES, DJU de 17/12/93, p. 28.049.

33 Vedando a assistência no processo de declaração de inconstitucionalidade, o $\$ 2^{\circ}$ do art. 169 do Regimento Interno do STF, acrescentado pela Emenda Regimental 2, de 04/12/85, teve sua recepçāo afirmada pelo STF no AgRg na ADIN 748 - 4 - RS (Pleno, ac. un., rel. Min. CELSO DE MELLO. RT 715/309).

34 Commentario breve alla costituzione. Padova: CEDAM, 1990. p. 787. 
Essa constatação também resulta de ALESSANDRO PIZZORUSSO quando assenta que as regras procedimentais estabelecidas para os juízos em via principal "se diferenciam das examinadas até agora, em virtude do caráter de processo «entre partes", que caracteriza estes procedimentos", ${ }^{35}$ para, linhas adiante, rematar: "Aplicam-se aos processos em via principal, normalmente, as normas já consideradas ao tratar dos juizos incidentais, se bem devem ter em conta as diferenças, derivadas de que aqui estamos ante um processo entre partes necessárias" ${ }^{36}$ Com base nessas considerações, aproveita o autor para suster a possibilidade de litisconsórcio. ${ }^{37}$

Nestas plagas, uma exceção nos aproxima do sistema praticado na Itália: é a ação direta interventiva, instaurada a fim de reprimir afronta aos princípios constitucionais sensíveis, enumerados, de forma taxativa, pelo art. 34, VII, da CF. Apesar de se tratar de controle pela via principal, está ante a processo entre partes, "cuja autora - acentuara OSWALDO ARANHA BANDEIRA DE MELLO - seria a União, representada pelo Procurador-Geral da República, e o Réu, o Estado federado, a que se atribuia haver violado o principio constitucional da União, e que devia ser citado na pessoa do seu representante legal, para deduzir a sua defesa, ante o Supremo Tribunal Federal. Na verdade, ocorre uma controvérsia jurídica entre partes sobre matéria sub judice" ${ }^{38}$

Sem nenhuma pretensão de aprofundamento do tema nestas páginas, é de observar uma certa similitude entre a demanda interventiva e a atribuição, deferida à Corte Constitucional pelo art. 134, $\mathrm{n}^{\circ}$ II, do Estatuto Máximo da República italiana, de solver os conflitos de atribuição entre os poderes do Estado e das Regiões, e entre os destas, cujo objetivo se volta para assegurar o respeito das normas constitucionais de organização. ${ }^{39}$

Também é de notar que, ao contrário da nossa Constituição, a qual prevê, expressamente. a possibilidade de concessão de medida cautelar (art. 102, $\mathrm{I}, p),{ }^{40} \mathrm{o}$ direito itálico é silente, havendo de ressaltar-se o seu não cabimento, consoante as

35 " se diferencian de las examinadas hasta ahora en virnd del carácter de processo "entre partes" que caracteriza a estos procedimientos". (Lecciones de derecho constitucional. Madrid : Centro de Estudios Constitucionales, 1984. t. II, p. 58).

36 "Se aplican a los processos en via principal, normalmente, las normas ya consideradas al tratar los juicios incidentales, si bien deben tenerse en cuenta las diferencias derivadas de que aqui estamos ante un processo entre partes necesarias". ( ibidem. p. 61).

37 ibidem, p. 61.

38 Teoria das constimições rígidas. 2. ed. São Paulo : José Bushatsky Editor, 1980. p. 192. No mesmo sentido, CLĖMERSON MERLIN CLĖVE (A fiscalização abstrata de constitucionalidade no direito brasileiro. São Paulo : Revista dos Tribunais, 1995. p. 102) e GILMAR FERREIRA MENDES (Controle de constitucionalidade; aspectos jurídicos e políticos. São Paulo : Saraiva, 1990. p. 222).

39 IVO DANTAS ( $O$ valor da Constituiçāo - Do controle de constitucionalidade como garantia da supralegalidade constitucional. Rio de Janeiro : Renovar. 1996. p. 61) considera a ação direta interventiva exemplo do pensamento de KELSEN, exposto no ano de 1928.

40 Tal prerrogativa, que se vem revelando de grande utilidade atualmente, decorrera da letra $p$, acrescentada ao art. 119, I, da Constituição pretérıta, pela EC 07/77. 
penas abalizadas de CRISAFULLI \& PALADIN,,${ }^{41}$ os quais fazem referência a outros doutrinadores que partilham da mesma opinião.

Outra divergência entre os arquétipos brasileiro e italiano está no que concerne à aferição de inconstitucionalidade por omissão. Esta, como frisa IVO DANTAS, "é de caráter negativo, ou seja, determinada a obrigação de legislar-se sobre matéria constante de norma que não seja de eficácia plena, não o fazendo o órgão para tal encarregado, configura-se a omissão e, conseqüentemente, a inconstitucionalidade". ${ }^{42}$

A Constituição de 1988, observando o exemplo das Constituições da República Socialista Federativa da Iugoslávia, de 1974 (art. 377), e a da República Portuguesa de 1976 (art. 279), previu um dispositivo, mais precisamente o seu art. 103, $\$ 2^{\circ}$, acolhendo o instituto, malgrado a falta de cominação de qualquer consequeência ao reconhecimento da ilegitimidade do legislador havê-la desprovido de qualquer efetividade.

Contrariamente, a Norma Ápice de 1947 restringiu a atuação controladora da Corte Constitucional às situações de transgressão positiva do seu texto, ou seja, com relação a leis, ou atos com a força destas, já existentes no cenário jurídico. Sanciona-se apenas a atuação material do legislador, postergando-se maiores conseqüências à sua inércia. Prova disso é que a utilização, nas pegadas do assentado pela Corte Constitucional (sentenza 14/1964), das normas programáticas como parâmetro aferidor de inconstitucionalidade se dá quando o legislador emite mandamento em contraposição direta ao seu programa.

Não confundir a inconstitucionalidade por omissão com as sentenze additive, a serem abordadas doravante, porquanto estas pressupõem a ilegitimidade de dispositivo legal existente, por a sua disciplina não haver abrangido certas situações, enquanto que aquela reclama o silêncio do legislador em regulamentar direito, liberdade, ou garantia constitucional.

Essa distinção não se apresenta apenas no controle por via de ação, mas também no incidental, uma vez a Lei Máxima nacional, ao contrário da italiana, acolher remédio jurídico, consubstanciado no mandado de injunção (art. $5^{\circ}, \mathrm{LXXI}$ ), com o escopo de assegurar ao interessado o exercício de direitos, liberdades constitucionais, ou prerrogativas inerentes à nacionalidade, à soberania e à cidadania, quando sua aplicação tornar-se inviável à míngua de norma regulamentadora, sem embargo de que a interpretação conferida ao instituto pelo Supremo Tribunal Federal haver-lhe retirado qualquer potencialidade de concreção. ${ }^{43}$

41 Commentario breve alla costimzione. Padova : CEDAM, 1990. p. 788.

42 O valor da Constituição - Do controle de constitucionalidade como garantia da supralegalidade constitucional. Rio de Janeiro : Renovar, 1996. p. 61.

43 Após um tímido desenvolvimento acerca dos efeitos da inovaçāo trazida com a Constituição de 1988 (MI 283 - DF, LEX JSTF 158/98: MI 232-1/400-RJ, LEX JSTF 167/105), o STF retrocedeu, de forma claudicante, à posição original. equiparando-a à ação direta de inconstitucionalidade por omissão, sendo nessa linha os acórdãos mais recentes (LEX JSTF 203/109, 196/96, 194/93 e 193/118). 
Um ponto a ser observado condiz com o quorum para a tomada de deliberações. Ex vi de injunção do art. 97 da Lei Magna, a declaração de inconstitucionalidade somente poderá ser tomada pelo Supremo Tribunal Federal mediante o voto da maioria absoluta dos seus membros, exigência estendida à ação direta de constitucionalidade (art. 23, caput, da Lei 9.868/99). Dessa maneira, não se alcançando tal votação, em virtude de licença ou ausência de alguns de seus ministros, o julgamento será sobrestado até o comparecimento dos ausentes (arts. 23, parágrafo único, da Lei 9.868/99, e 173, parágrafo único, RISTF). Indispensável, portanto, o voto de seis ministros para que o reconhecimento da inconstitucionaldade produza os seus efeitos. Ademais, exige-se, para que se possa iniciar a discussão sobre a constitucionalidade ou inconstitucionalidade, a presença de, no mínimo, oito ministros à respectiva sessão.

Segundo o art. 16 da Lei 87/53, o funcionamento da Corte Constitucional depende da presença de, pelo menos, onze de seus integrantes, devendo participar da deliberação os juízes que estiveram presentes a todas as audiências relativas ao feito, não sendo permitida qualquer substituição, salvo se para completar o número mínimo para a instalação da audiência de julgamento. As decisões são tomadas mediante a maioria dos juízes, possuindo o presidente voto de qualidade em caso de empate. Assim, tem-se que a inconstitucionalidade poderá ser reconhecida com o voto de seis juízes, ainda que a Corte seja composta de quinze membros, o que seria aqui inadmissível em face do art. 97 da atual Constituição.

\section{VI - Atos impugnáveis}

Neste tópico, nossas atenções voltar-se-ão à busca de quais atos estão sujeitos ao exame do Supremo Tribunal Federal e da Corte Constitucional italiana, no desenrolar da fiscalização de legitimidade constitucional por via de ação direta e, no que tange à segunda, tanto em forma principal quanto incidental. Será, assim, delimitada pela confrontação entre os arts. 102, I, letra $a$, da Norma Básica de 1988, e $134, n^{\circ}$ I, da Constituição da Itália, com o propósito de se listar as principais diferenças entre os dois sistemas.

O primeiro aspecto condiz ao conceito de lei, ou ato normativo, capaz de ensejar a ativação do contencioso de constitucionalidade. Entre nós, prevalece o entendimento de que não basta o ato emanar do cumprimento das formalidades do processo legislativo (lei formal), sendo indispensável ainda que ostente generalidade e abstração, sujeitando sob o seu comando situações concretas e pessoais.

Com vistas a fincar importante premissa em tema de controle de constitucionalidade, o Supremo Tribunal Federal, na ADIN 647-DF, relatada pelo Min. MOREIRA ALVES, ${ }^{\text {t4 }}$ manifestou-se pelo não cabimento da ação ajuizada. Impugnava-se dispositivos da Lei 8.029/90 (arts. $7^{\circ}$ e $9^{\circ}$ ), que autorizavam o Poder Executivo a transferir o acervo técnico, físico, material e patrimonial da Fazenda Experimental

44 Pleno, RTJ 140/36. 
do Café, situada no Município de Varginha (MG), e do Programa Nacional de Melhoramento da Cana-de-Açúcar, para a Empresa Brasileira de Pesquisa Agropecuária-EMBRAPA, juntamente com a transferência de bens de autarquias e fundações à União. Em seu voto, o relator, no que fora acompanhado sem discrepância, assentara que a ação direta de inconstitucionalidade, sendo meio pelo qual o Judiciário realiza a sua função de fiscalizar a constitucionalidade de normas jurídicas em abstrato, não se prestava para aferir a legitimidade constitucional de atos que, embora editados sob a roupagem de lei, consubstanciam atos administrativos, possuidores de objeto determinado e destinatários certos. Noutra oportunidade, embora sem unanimidade de votos, não se conheceu da ADIN 842-DF, ${ }^{45}$ dirigida contra o art. 56 da Lei 8.541/92, ao autorizar o Ministro da Fazenda a convocar para a segunda etapa do concurso público para o provimento do cargo de Auditor Fiscal do Tesouro Nacional, relacionado com o Edital 18/91, da Escola de Administração Fazendária, os candidatos habilitados na $1^{\text {a }}$ etapa e classificados além do quiingentésimo. Ainda no mesmo sentido, há decisão não admitindo seja intentada ação direta perante lei orçamentária anual (Lei 9.438/97), por entender que a norma atacada reflete, na verdade, ato administrativo e não conteúdo de lei. ${ }^{46}$

Contrariamente, o direito italiano vem influenciado pelo critério exclusivamente formal, prescindindo da generalidade e da abstração do objeto controlado. É o que se percebe da doutrina, conforme ressalta FAUSTO CUOCULO, ao delimitar o alvo da fiscalização: "Tais são, de fato, aqueles atos que apresentam os elementos formais mínimos, indispensáveis para serem considerados leis". ${ }^{47} \mathrm{Na}$ mesma linha, GIUSEPPE DE VERGOTTINI quando, a pretexto de enumerar os atos sujeitos à sindicação da Corte, menciona "as leis ordinárias do estado, a prescindir do seu conteúdo, o qual pode ser também substancialmente administrativo (leis-providências)". ${ }^{48}$

Outra faceta que separa os dois sistemas se dá a propósito das leis anteriores à Constituição. A possibilidade de se reputá-las derrogadas, quando contrastem com normas constitucionais posteriores, provoca dissenso, a se refletir no cabimento da instauração do contencioso constitucional.

O Supremo Tribunal Federal, em posição forjada quando da malsinada representação de inconstitucionalidade, com ratificação perante a nova ordem sobranceira, inclinou-se na direção de que a hipótese não patenteia inconstitucionalidade, mas revogação, sendo, portanto, descabida a sua suscitação como fundamento para a

45 Pleno, Rel. Min. CELSO DE MELLO, RTJ 147/545.

46 Pleno. ADIN 1.640 - DF, ac. un., rel. Min. SIDNEY SANCHES. julg. cm 12/02/98, Informativo STF 99.

47 "Tali sono, infatti, quegli atti che presentano gli elementi formali minimi indispensabili per essere considerati leggi". (Principi di diritto costituzionale. Milano : Giuffrè, 1996. p. 743).

48 "le leggi ordinarie dello stato, a prescindere dal loro contenuto che può essere anche sostanzialmente amministrativo (leggi-provvedimento)". (Diritto costituzionale. Padova : CEDAM, 1997. p. 626). A mesma idéia pode ser vislumbrada em BISCARETTI DI RUFFIA (Diritto costituzionale. 15. ed. Napoli : Jovene, 1989. p. 664) e em CRISAFULLI \& PALADIN (Commentario breve alla costituzione. Padova : CEDAM, 1990. p. 776). 
propositura de ação direta. Prevaleceu a crença inabalável de que, se uma lei é inconstitucional quando o legislador exorbita os poderes que lhe foram assinados pela Constituição, é porque se trata da Lei Maior vigente quando da atuação legislativa, já que aquele não deve obediência à Constituição antiga, já revogada, nem à Constituição futura, a qual não existia quando da formação da regra de direito e, portanto, não poderia limitar a sua atividade. ${ }^{49}$

O exemplo italiano se pautou em senda oposta. A Corte Constitucional, em foros de definitividade, resolveu o problema, assentando a plena verificação da inconstitucionalidade das leis anteriores diante da Lei Máxima, desde que decorrentes de vícios materiais, configurando-se o que se pode denominar de incostituzionalità materiale sopravvenuta (inconstitucionalidade material sobrevinda ou superveniente), orientação materializada na sentenza 01/1956 e em outras que lhe sucederam. De destacar, no corpo do paradigma líder, o trecho seguinte: " $O$ assunto, segundo o qual o novo instituto da ilegitimidade constitucional somente se refere às leis posteriores à Constituição, e não também àquelas anteriores, não pode ser acolhido, seja porque, do lado textual, tanto o art. 134 da Constituição quanto o art. $1^{\circ} \mathrm{da}$ lei constitucional de 9 de fevereiro de 1948, $n^{\circ} 1$, falam de questões de legitimidade constitucional das leis, sem fazer alguma distinção; seja porque, do lado lógico, é inegável que o relacionamento entre leis ordinárias e leis constitucionais, e o grau que a elas, respectivamente, compete na hierarquia das fontes, não muda inteiramente, sejam as leis ordinárias anteriores, sejam posteriores àquelas constitucionais". ${ }^{50}$

49 O posicionamento vencedor se acha exposto pelo Min. PAULO BROSSARD em trabalho de doutrina (A constituição e as leis a ela anteriores. Arquivos do Ministério da Justiça. Brasília, a. 45 , n. 180 , p. 125-148, jul./dez. 1992), onde são mencionados inúmeros precedentes do STF durante as ordens constitucionais anteriores, entre os quais podem ser indicados: RT 231/665, RTJ 71-291, $76 / 538,82 / 44,95 / 980,95 / 993,98 / 952,99 / 544,116 / 652,109 / 1.220,124 / 415$ e DJU de 01/08/86, bem como o fato de que, em 06-02-92, data em que ultimado o julgamento da ADIn. 2, de 1988, de sua relatoria, a Excelsa Corte reafirmara sua postura anterior, decidindo, logo após, trinta e duas açōes idênticas. Em que pese o ponto de vista majoritáric. somos da opinião de que mais ajustado aos dias atuais estava o voto discordante do Min. SEPÚLVEDA PERTENCE, malgrado contra este pudesse conspirar a falta de rigor acadêmico. Sem a menor dúvida, a posição defendida por $S$. Exa., cujas razōes, acompanhadas pelos Ministros NÉRI DA SILVEIRA e MARCO AURÉLIO, foram iguaimente reduzidas ao universo doutrinário (Ação Direta de Inconstitucionalidade e as normas anteriores: as razões dos vencidos. Arquivos do Ministério da Justiça, Brasília, a. 45, n. 180, p. 149-174. jul./dez. 1992), postam-se mais afinadas com o objetivo do controle concentrado da constitucionalidade, qual seja o de proporcionar certeza ao sistema jurídico, com a solução mais rápida de suas antinomias, a qual, se confiada às várias instâncias da jurisdição difusa, levaria longos anos para ser resolvida, com enormes prejuízos aos jurisdicionados. Ademais, bem disse S. Exa.. forte em NORBERTO BOBBIO, nada impede que dada contradição sistemática possa ser afastada pela aplicação de mais de um dos critérios hábeis para tanto (cronológico, hierárquico e o da especialidade), sobrelevando que o qualificativo de revogação não exclui cogitar-se o desacordo entre a lei anterior e a Constituição como sendo primariamente uma relação de inconstitucionalidade. so "L'assunto che il nuovo istituto della illegitimità costituzionale si riferisce soío alle leggi posteriori alla Costituzione e non anche a quelle anteriori, non può essere accolto sai perché, dal lato testuale, tanto l'art. I34 della Costituzione quanto l'art. I della legge costituzionale 9 febbraio 
Ao revés, não aceitou que tal ocorresse por vício formal, ou procedimental, dada a impossibilidade de retroação das novas normas constitucionais disciplinadoras da formação das leis (sentenza 04/1959 e posteriores).

Interessante notar, como informa ALESSANDRO PIZZORUSSO, ${ }^{51}$ ser, de acordo com a tendência mais difundida na Itália, plenamente admissível a coexistência entre inconstitucionalidade e derrogação, tocando a primeira à Corte Constitucional, cuja decisão é eficaz erga omnes, enquanto que a segunda, pertencendo à alçada das justiças ordinária e administrativa, surtirá efeitos apenas no caso concreto.

Quanto ao decreto-legge do art. 77 do Estatuto Magno italiano, instituto aqui recepcionado através da medida provisória do art. 62 da Constituição, também se pode colacionar divergência quanto à sua sujeição ao controle de constitucionalidade.

Apesar de favorável à impugnação do decreto-legge, a Corte Constitucional italiana, tal como ilustrado nas sentenze $75 / 1967$ e 84/1974, restringe-a ao momento posterior à sua conversão em lei, se bem que o faz com referência aos efeitos produzidos no período de sua provisória vigência.

Por sua vez, o Supremo Tribunal Federal admite que o controle, via ação direta, principie antes mesmo da transformação em lei da medida provisória, ${ }^{52}$ se bem que o vezo da reedição tenha vindo a servir de obstáculo ao êxito da atividade fiscalizadora, haja vista a necessidade intransponivel de aditamento, mesmo quando a medida renovada guarde identidade substancial com relação àquela atacada. ${ }^{53}$

Discrepância pode ser visualizada quanto à possibilidade de controle do desenvolvimento da competência regulamentar. A Corte Constitucional, à consideração de que o art. 134, $\mathrm{n}^{\circ}$ I, da Constituição de 1947, perfilhara critério formal, afirmou, na sentenza 21/1980, e, posteriormente, na sentenza 484/1993, que a jurisdição constitucional não pode ser impulsionada para questionar regulamentos administrativos, ainda que estes contenham normas primárias (regulamentos independentes). Isso, contudo, não impede que os juízes administrativos possam, diante dos conflitos de interesses que lhes são trazidos, anulá-los, em virtude de eventual vício de constitucionalidade.

Essa possibilidade consta de passagem extraída da sentenza 484/1993: “ a assumida violação do parâmetro constitucional evocado pode ser sempre averiguada,

$1948, n^{\circ} 1$, parlano di questioni di legittimità costituzionale delle leggi, senza fare alcuna distinzione, sai perché, dal lato logico, è innegabile che il rapporto tra leggi ordinarie e leggi costituzionali e il grado che ad esse rispettivamente spetta nella gerarchia delle fonti non mutano affatto, siano le leggi ordinarie anteriori, siano posteriori a quelle costituzionali". (Cf. LIVIO PALADIN, Diritto costituzionale. 2. ed. Padova: CEDAM, 1995. p. 747).

51 Lecciones de derecho constitucional. Madrid: Centro de Estudios Constitucionales, 1984. t. II. p. 22.

52 Pleno, ADIMC 162 - DF, mv, rel. Min. MOREIRA ALVES, julg. em 14/12/89, DJU de 19/09/97; ADIN 1.397-1 - DF, Pleno, mv, rel. Min. CARLOS VELLOSO, DJU de 27/06/97; ADIN 1.753 2/DF, Pieno, ac. un., rel. Min. SEPÚlVEDA PERTENCE, DJU de 12/06/98.

53 AgRgADIN 1.387, Pleno, ac. un., rel. Min. CARLOS VELLOSO, DJU de 29/03/96. 
incidentalmente, pelo juiz ordinário, para o fim da desaplicação da norma regulamentar". ${ }^{54}$

Esse entendimento alcançou alargamento, para o fim de justificar a impossibilidade da investigação de constitucionalidade com relação aos regulamentos da Corte Constitucional (sentenza 572/90) e aos regulamentos parlamentares (sentenza 154/85). Essa postura mereceu sólida censura por parte de ROBERTO GAROFOLI, ${ }^{55}$ o qual, apoiando-se na premissa de que tais regulamentos provêem de competência de porte constitucional, afirma serem portadores de primariedade, de sorte a identificarem-se com os atos com força de lei. ${ }^{56}$

O pensar prestigiado pelo Supremo Tribunal Federal, exemplificado pela razão de decidir contida na ADIN 708- $\mathrm{DF}^{57}$, biparte os regulamentos em executivos e autônomos, não admitindo o ajuizamento de ação direta quanto aos primeiros, porquanto, atritando-se com a lei regulamentada, padecem da mácula da ilegalidade. Já quanto aos segundos, a que se assemelham os regolamenti indipendenti, seria cabível a medida, a fim de aferir se a autoridade administrativa se afastara dos lindes de atuação demarcados sobranceiramente.

Em suma, demanda o Supremo Tribunal Federal a presença de dois pressupostos, a saber: a) o caráter de lei material (regra de direito) do preceito impugnado; b) não se mostrar a disposição acoimada de inconstitucional na condição de propiciar a execução de norma legal, porquanto estar-se-ia diante de ilegalidade e não de inconstitucionalidade, esta última consistindo em defeito da lei regulamentada.

Essa orientação alcança os regimentos internos dos tribunais, elaborados em atenção à competência a estes deferida pelo art. 96. I, $a$, da CF. Segue-se daí que, enquanto ofendam as leis de processo, os dispositivos regimentais perpetrariam ilegalidade, não desafiadora de ação direta, hipótese que se verificará quando contrastarem diretamente com o texto da Constituição. Mutatis mutandi, idêntica disciplina observam os regimentos das casas legislativas.

Noutros aspectos, são lembradas algumas semelhanças entre os sistemas enfocados, quais sejam as inerentes à: a) possibilidade de serem as emendas constitucio-

54 "l'assunta violazione del parametro costituzionale evocato può essere sempre accertata incidentalmente dal giudice ordinario al fine della disapplicazione della norma regolamentare ". (Apud ROBERTO GAROFOLI, Sulla Sindacabilità in Sede di Giudizio di Legitimità dei Regolamenti della Corte Costituzionale. Rivista trimestrale di diritto pubblico, n. 3, p. 665-718, 1997).

55 Sulla Sindacabilità in Sede di Giudizio di Legitimità dei Regolamenti della Corte Costituzionale. Rivista Trimestrale di Diritto Pubblico, n. 3, p. 665-718, 1997).

56 Em sua exposição, aponta o autor (ibidem, p. 681-687), com o intento de justificar a fonte constitucional da competência normativa da Corte, a existência, no manancial doutrinário, de duas vertentes, a entenderem ora que se trata de poder expresso (a emanar dos arts. 14 e 22 da Lei 87/53. cujo status constitucional é reconhecido em face do art. $1^{\circ}$ da Lei Constitucional $01 / 53$ ). ora implícito, decorrente de sua natureza de órgão constitucional. sito em posição de independência ante os demais poderes estatais. Já quanto aos regulamentos parlamentares, acrescenta (ibidem, p. 704-706), a sua origem magna resulta do art. 64 da Lei Maior de 1947.

57 Pleno, ac. un., rel. Min. MOREIRA ALVES, RTJ 142/718. 
nais (e, na Itália, também as leis constitucionais) ${ }^{58}$ passíveis de submissão ao controle de constitucionalidade, em face da desobediência às limitações impostas ao poder constituinte derivado, quer formais (limitações circunstanciais e procedimentais), quer materiais (cláusulas pétreas), ${ }^{59}$ b) encontrarem-se excluídos do contencioso constitucional os atos normativos estrangeiros, entre os quais se incluem, para o direito italiano, os regulamentos comunitários, ressalvada, no entanto, a possibilidade de aferição da legitimidade constitucional dos atos que impliquem na incorporação ao sistema dos tratados e convenções, visto que são considerados atos de direito interno; ${ }^{60} \mathrm{c}$ ) lei delegada, inclusive com o fim de verificar a adequação à Lei Magna do ato de delegação. ${ }^{61}$

\section{VII - Parâmetros}

Impende aqui verificar quais os padrões que devem ser levados em conta, tanto pelo Supremo Tribunal Federal, quanto pela Corte Constitucional italiana, no julgamento das questões constitucionais que a eles são submetidas. O resultado, adiantese, importará em maior aproximação dos sistemas do que em seu distanciamento.

Em primeiro lugar, emerge a conclusão de que o juízo de constitucionalidade terá, como baliza, o ordenamento constitucional formal, composto dos dispositivos contidos na parte permanente e nas disposições transitórias, e, com especificidade para o modelo italiano, também pelas leis constitucionais.

58 Interessante, de logo, salientar que, em solo italiano, o poder constituinte derivado do Estado (art. 138 da Constituição) se exerce mediante o uso de duas espécies normativas: a) as leis de revisão constitucional, veiculadoras de emendas ou modificaçōes no texto constitucional; b) as leis constitucionais (ou de integração), voltadas ao complemento da Lei Máxima, podendo incidir, como sistematiza CRISAFULLI (Lezioni di dirito costituzionale. 6. ed. Padova : CEDAM, 1993. p. 85), nas seguintes situaçōes: a) quando há referência expressa do Constituinte (arts. $71,116,117, \mathrm{n}^{\circ} 2$, 132. 137 e XI das disposições transitórias); b) nas matérias privadas de forma constitucional por óbice implícito, o qual pode ser removido (melhor dizendo, derrogado) pela lei constitucional, sem que. para tanto, venha substituir o teor da norma que imponha tal limitação; c) todos os assuntos em que o Parlamento tenha julgado que a sua disciplina deva fazer-se mediante lei constitucional. 59 Sob o império da Constituição de 1988, o STF, em mais de uma oportunidade (Pleno, ADIN 939 - DF, mv, rel. Min. SYDNEY SANCHES, RTJ 151/755: Pleno, ADINMC 1.946, ac. un., rel. Min. SYDNEY SANCHES, julg. em 07/04/99, Informativo - STF $n^{\circ}$ 144), admitiu tal hipótese.

60 Cf., a respeito, as sentenze 90/1965, 20/1966, 183/1973 e 18/1982. da Corte Constitucional. Diferente não se mostra a jurisprudência do STF, consoante precedentes afirmados nas RTJ $84 / 724$ e $121 / 270$ e, recentemente, na ADINMC $1.480-3$ - DF (Pleno, mv, rel. Min. CELSO DE MELLO, julg. em 04/09/97, Informativo - STF $n^{\circ} 82$ ), ajuizada contra o Decreto 1.855/96, responsável pela promulgação da Convenção 158 da OIT, sustentando que os tratados e convençōes internacionais, quando integrados à ordem jurídica pátria, possuem o caráter de lei ordinária.

61 Em face da maior frequiência da delegação legislativa, devido à estrutura parlamentar de governo da Itália, a Corte Constitucional italiana, ao contrário do STF, já se defrontara com o tema em várias oportunidades (cf. sentenze 39/1959, 129/1963, 106/1967 e 28/1970). 
De observar que, em ambos os campos de análise, a inconstitucionalidade poderá advir, inicialmente, de vícios formais, quando desrespeitados os dispositivos constitucionais sobre o procedimento de formação do ato atacado.

Nesse ponto, a Corte Constitucional italiana, ao depois da superação do dogma da separação de poderes, na forma em que perfilhado pelo Estatuto Albertino, amostra de documento flexível, passou a admitir o controle dos atos interna corporis, calcado na atividade procedimental realizada no interior das câmaras quando da elaboração das leis. Exige-se apenas, conforme resulta das sentenze 09/1950 e 134/1969, que a fiscalização se faça com referência ao maltrato de disposições constitucionais.

O combate à infração ao processo legislativo não escapou ao descortino do Supremo Tribunal Federal, o qual não se recusa a investigar, sob o plano formal, a violação das normas constitucionais que regulam a elaboração das leis. Exemplos estão nas ADINMC $2.182-\mathrm{DF}^{62}$ e $2.235-\mathrm{AP}^{63}$. Preciso não confundir com a conceituação restrita que a nossa Excelsa Corte traça sobre as questões interna corporis, condizentes ao desacato de normas regimentais, cuja solução pertence, unicamente, ao Legislativo, descabendo revisão pelo Judiciário ${ }^{64}$.

Com maior razão, são perscrutados os vícios substanciais, concernentes à violação, pelo preceito impugnado, do conteúdo, expresso ou implícito, das demais normas da Constituição formal, inclusive dos princípios informadores desta. De advertir, porém, não ser de bom tom falar em hierarquia entre normas advindas do Constituinte originário, no sentido de que algumas delas seriam inconstitucionais perante outras, fundadas em valores suprapositivos consagrados pela Lei Fundamen$\mathrm{tal}^{65}$.

Critério aproximativo dos modelos sob cotejo é o que permite ao julgador, no exercício da fiscalização de constitucionalidade, controlar os atos normativos, notadamente quando restritivos de direitos, sob o prisma da razoabilidade, de modo a se investigar se o legislador atuou de maneira arbitrária ou aberrante da razão. O seu terreno privilegiado de incidência, como expõe OMAR CHESSA ${ }^{\text {th }}$, liga-se ao juízo

62 Pleno, mv, rel. Min. MAURÍCIO CORRÊA, Informativo - STF $n^{\circ} 191$.

63 Pleno, ac. un., rel. Min. OCTÁVIO GALLOTTI, Informativo - STF n ${ }^{\circ}$ 195. Consultar também: Pleno, ac. un., ADIN 1.254 - RJ, rel. Min. SEPÚLVEDA PERTENCE. Informativo - STF $\mathbf{n}^{\circ} 174$; Pleno, ac. un., ADIN 774 - RS, rel. Min. SEPÚLVEDA PERTENCE. Informativo - STF ${ }^{\circ} 135$. 64 Cf. pleno, ac. un. MS 20.247 - DF, rel. Min. MOREIRA ALVES, RTJ 102/27; pleno, ac. un., MS 20.464 - DF, rel. Min. SOARES MUÑOZ, RTJ 112/598; Pleno, ac. un.. ADIN 2.038 - BA, rel. desig. Min. NELSON JOBIM, Informativo - STF $n^{\circ} 158$. Chamo atenção para o MS 22.503 - DF (Pleno. mv, rel. desig. Min. MAURÍCIO CORRÊA, DJU de 06/06/97. pág. 24.872), em cujo texto se acha cristalina a diferenciação entre a violação de normas constitucionais inerentes ao processo legislativo, cujo questionamento faz-se possível, e a ofensa de disposiçōes regimentais, a circunscreverem o espaço de economia doméstica do Legislativo, imune à jurisdição.

65 Cuida-se da tese alemã da inconstitucionalidade das normas constitucionais, cujo rechaço consta dos anais do STF (Pleno, ADIN 815-3 - DF, ac. un., rel. Min. MOREIRA ALVES, DJU de 10/05/96).

66 Bilanciamento bem temperato - O Sindacato Esterno di Ragionevolezza? Note sui Diritti 
de igualdade, previsto no art. $3^{\circ}$ da Constituição da Itália, a fim de constatar se a discriminação legislativa é justificável.

Discorrendo sobre a ragionevolezza, a qual qualifica como una parola magica (uma palavra mágica), afirma ROBERTO BIN $^{67}$ que a aferição daquela impõe diligências ao magistrado, entre as quais valorar se: a) a finalidade perseguida pelo legislador não é abertamente ilegítima, b) a disposição questionada configura um instrumento apto à realização do fim visado; c) o legislador, para alcançar o objetivo pretendido, não poderia servir-se de meios igualmente hábeis, mas menos gravosos.

A Corte Constitucional tem feito uso do critério em várias ocasiões, ilustradas, dentre muitas, pelas sentenze 133/1970, 108/1986, 197/1981 e 195/1982. Da mesma forma, o Supremo Tribunal Federal vem, ao menos desde a Constituição de 1946, buscando serventia na razoabilidade para controlar eventuais abusos legislativos. Consultar: RE 18.331, ${ }^{68} \mathrm{HC} 45.232,{ }^{69} \mathrm{Rp} 930$ - DF, ${ }^{70} \mathrm{Rp} 1.077$ - RJ, ${ }^{71} \mathrm{Rp} 1.054$ - DF, ${ }^{72}$ ADIN 855 - 2/PR, ${ }^{73}$ ADIN 1.040 - 9/600, ${ }^{74}$ ADINs $966-4$ e $958-3,{ }^{75}$ ADIN $1.158-8 / \mathrm{AM}^{76}$ ADIN $1.753-2 / \mathrm{DF}^{77}$ e ADIN $2.019-\mathrm{MS}^{78}$

Ainda no diapasão do julgamento de razoabilidade, de notar que a Corte Constitucional, na sua atividade, não deixa de lançar mão do método do bilanciamento degli interessi (balanceamento dos interesses), a fim de resolver eventual conflito entre princípios constitucionais, conforme deflui das sentenze 363/91 e 467/91.

Nesse particular, tem-se mostrado mais tímido o Judiciário nacional. Ao indeferir liminar na ADIN 223 - DF, voltada contra a proibição de liminares contidas na MP 173/90, assentou o Supremo Tribunal Federal, na linha do voto vencedor do Min. SEPÚLVEDA PERTENCE ${ }^{79}$ a dificuldade de se demarcar, em tese, máxime em juízo de delibação, a ponderação entre a garantia da ordem pública, ameaçada pelo abuso do poder cautelar, e o cerceamento da universalidade de jurisdição, a fim de que fosse, de pronto, examinada se a providência legislativa desbordara da razoabilidade. Entendeu-se mais apropriado confiar tal a cada um dos magistrados no exame do caso concreto que lhe for submetido.

Inviolabili come Parametro del Giudizio di Costituzionalità. Giurisprudenza costituzionale. Milano: CEDAM, a. XLIII, n. 6, p. 3926, nov./dic. 1998.

67 Capire la costituzione. Roma: Editori La perza, 1998. p. 104-106.

68 2: Turma, ac. un., rel. Min. OROZIMBO NONATO, RF 145/164-169.

69 Pleno, mv, rel. Min. THEMísTOCLES CAVALCANTI, RTJ 44/322.

70 Pleno, mv, rel. desig. Min. RODRIGUES ALCKMIN, DJU de 02/09/77.

71 Pleno, ac. un., rel. Min. MOREIRA ALVES, RTJ 112/32.

72 Pleno, rel. desig. Min. MOREIRA ALVES, RTJ 110/937.

73 Pleno, mv, rel. Min. SEPÚl VEDA PERTENCE, DJU de 01/10/93.

74 Pleno, mv, rel. Min. NÉRI DA SILVEIRA, DJU de 17/03/95.

75 Pleno, mv, rel. Min. MARCO AURÉLIO, DJU de 11/05/94.

76 Pleno, mv, rel. Min. CELSO DE MELLO, DJU de 26/05/95.

77 Pleno, ac. un., rel. Min. SEPÚlVEDA PERTENCE, DJU de 23/10/98.

78 Pleno, ac. un., rel. Min. ILMAR GALVĀO, RTJ 171/800.

79 RTJ 132/571. 
Outro parâmetro de controle, cujo maior desenvolvimento se manifestara na Itália, respeita ao problema da normatividade interposta, isto é, de normas que, ex $v i$ de disposições formalmente constitucionais, são reclamadas como condições de validade de leis, em setores determinados.

Assim, tem-se que: a) os decretos legislativos, introdutores de leis delegadas, hão de conformar-se aos princípios e critérios diretivos estatuídos na lei de delegação, por injunção do art. 76 da Constituição de 1947, pena de inconstitucionalidade (sentenze 39/1959, 129/1963, 106/1967 e 28/1970); b) os princípios fundamentais, constantes das leis do Estado, devem servir de limite às leis regionais, conforme o art. 117 da Constituição; c) a vinculação das leis regionais de referendo consultivo à legislação do Estado, mencionada no art. 133 da Lei Maior (sentenza 107/1983); d) as normas de direito internacional geralmente reconhecidas, às quais deve se conformar o ordenamento italiano, nos termos do art. 10 da Lei Maior.

Especificamente quanto à última das hipóteses, digno de atenção o comentário de GIUSEPPE DE VERGOTTINI, ao momento em que, sem embargo de a firmar que as normas internacionais inseridas no ordenamento italiano em razão do instituto da adaptação automática, prevista no art. 10 da Lei Fundamental peninsular, não ostentam uma posição superior àquelas fruídas pelas normas constitucionais, timbra em sublinhar que "considerada a vontade do constituinte de assegurar relevância e observância aos costumes internacionais, é evidente também que os órgãos do estado italiano não podem adotar atos que se ponham em contradição com o quanto neles disposto. De conseqüencia, a Corte constitucional considera ilegítimas as normas legais em contraste com os costumes (13571963, 48/1967)".80

Mais retraído, o direito brasileiro não descarta totalmente o problema das normas interpostas como paradigma para a declaração de inconstitucionalidade. Tal vem ocorrendo quando a regra de direito impugnada usurpa território demarcado, pela Constituição, à lei complementar.

Uma evolução da jurisprudência do Supremo Tribunal Federal bem coloca a problemática. Principio pelo RE $84.994-\mathrm{SP}^{81}$ no qual restou declarado inconstitucional o acréscimo do art. $1^{\circ}$ da Lei 10.421 , de 03/12/71, do Estado de São Paulo,

80 "considerata la volontà del costituente di assicurare rilevanza e osservanza alle consuetudini internazionali è anche evidente che gli organi dello stato italiano non possono adottare atti che si pongano in contraddizione con quanto disposto. Di conseguenza la Corte costituzionale considera illegittime le norme di legge in contrasto con le consuetudini (135/1963, 48/1967)". Diritto costituzionale. Padova : CEDAM, 1997. p. 37-38. Acresça-se as decisōes 67/1961, 104/1969, 169/1971 e 69/176. Peculiaridade retratou a discutida sentenza 48/1979, a qual, com base no critério da especialidade, deliberou pela prevalência do costume internacional da imunidade do diplomata, de nacionalidade estrangeira, com relação à jurisdição civil, mesmo que o seu contendor, em virtude dessa circunstância, ficasse privado do direito de acesso à justiça, garantido pelo art. $24, \mathrm{n}^{\circ} 1$, da Constituição de 1947.

81 Pleno. ac. un., rel. Min. XAVIER DE ALBUQUERQUE, RTJ 87/204. 
uma vez não encontrar apoio nos art. 113 e 201, ambos do Código Tributário Nacional. Não obstante se posicionar no sentido do voto do relator, e do Ministro CUNHA PEIXOTO, o Min. MOREIRA ALVES votou pela alteração da forma em que posta, originariamente, a decisão, propensa ao provimento do recurso. Para tanto, asseverou: "Parece-me, entretanto, que o conflito da norma ordinária estadual com dispositivos do Código Tributário Nacional (lei complementar) acarreta, não a ilegitimidade ou a ilegalidade daquela, mas, sim, a sua inconstitucionalidade, por invasão indébita em área reservada, pela Constituição Federal, à lei complemen$t^{\prime a r}{ }^{\prime 82}$. Bastou essa ponderação, acompanhada da menção afirmativa de escólios doutrinários, a fim de que o resultado final concluísse, na via incidental, pelo reconhecimento da incompatibilidade vertical do dispositivo cuja execução se impugnava.

Passado algum tempo, pareceu refluir a posição da Suprema Corte, ainda agitada na via de exceção, quando, no Agravo de Instrumento 88.456 - $\mathrm{SP}^{83}$, reconheceu que a violação de lei complementar se equiparava à de lei ordinária, não ensejando o conhecimento de recurso extraordinário.

Durante o descortino da Rp 1.141-MA ${ }^{84}$, assestada contra o Assento 17/80 do Tribunal de Justiça do Maranhão, que dispunha sobre o período de férias forenses de seus integrantes, decidiu-se que, uma vez ferido o art. $66, \S 1^{\circ}$, da Lei Complementar 35/79, violado remanescia também o art. 112, parágrafo único, da Constituição Federal revogada, o qual destinava à lei complementar, de competência da União, dispor sobre o assunto.

A esses exemplos, transcorridos à época da vigência da Constituição de 1969 , pode ser aditada a ADINMC 1.480-3-DF ${ }^{85}$, onde se discutia sobre a legitimidade do ato de trasladação ao nosso ordenamento da Convenção 158 da OIT, haja vista que um dos autônomos fundamentos do voto do relator, Min. CELSO DE MELLO, partira, justamente, da consideração de que, a despeito dos tratados e convenções internacionais guardarem paridade normativa com o ordenamento infraconstitucional, não poderiam disciplinar matéria sujeita à reserva de lei complementar.

82 RTJ 87/210. Ainda merecedora de transcrição passagem do voto do Min. THOMPSON FLORES, então ocupante da Presidência do Augusto Sodalício: "Embora o preceito local conflite com as disposições dos arts. 113 e 201 do Código Tributário Nacional, reconheço também que melhor correção juridica serú declarar sua inconstitucionalidade em lugar de reconhecer a ilegitimidade da cobrança, expressão adotada preferentemente na ltália e por alguns julgados do Supremo Tribunal Federal (RE número 79.822, Primeira Turma, em 17/2/75, Relator Ministro Aliomar Baleeiro). $O$ que, em verdade, faz prevalecer sobre a norma local impugnada, é a autorização prevista no art. $18, \S 1^{\circ}$. em conjugação com o art. $8^{\circ}$. XVIII, ambos da Constituição." (RTJ $87 / 213.214)$.

83 I'T., ac. un., rel. Min. ALFREDO BUZAID, RTJ 103/1.062.

84 Pleno, ac. un., rel. Min. DÉCIO MIRANDA, RTJ 105/487.

85 Pleno, mv, julg. em 04/09/97. Informativo - STF $n^{\circ} 82$. 
$\mathrm{Na}$ perspectiva a ser seguida, traçaremos um panorama, conquanto singelo, acerca das deliberações da Corte Constitucional italiana. À medida que desenvolvido o assunto, procederemos à comparação ante a realidade nacional.

De pronto, é de salientar a divisão entre as decisōes que examinam o mérito da discussão suscitada (sentenze) e aquelas de conteúdo meramente processual (ordinanze). Estas últimas são as deliberações que, por diversos motivos (falta de legitimação do órgão suscitante, não possuir a disposição indicada força de lei, não ser o questionamento relevante, for manifestamente infundada a dúvida de inconstitucionalidade etc.), não admitem seja agitado o contencioso constitucional. São adotadas em procedimentos mais simples, como a deliberação em câmara, sem necessidade de audiência pública.

Quanto às diversas modalidades de ações diretas, a sua impropriedade, normalmente, é de ser reconhecida quando do julgamento, pelo Supremo Tribunal Federal, de pedido de cautelar, ou do mérito, admitindo-se possa, monocraticamente, o relator fazê-lo quando a inicial for inepta, ou não estiver fundamentada, ou o pleito for manifestamente improcedente, cabendo do despacho agravo (arts. $4^{\circ}$, parágrafo único, e 15, parágrafo único, Lei 9.868/99), prerrogativa que cuidara o legislador de estender à argüição de descumprimento de preceito fundamental (art. $4^{\circ}, \S 2^{\circ}$, Lei 9.882/99).

Voltando-se nossos cuidados às decisões de mérito, principiamos pelas sentenze d'accoglimento, as quais reconhecem fundadas as questões de constitucionalidade submetida à Corte Constitucional, em via incidental ou principal, e, em consequiência, declaram a ilegitimidade constitucional das disposições impugnadas.

A primeira indagação reporta-se à sua eficácia temporal, tendo, para a sua solução, o art. 136 da Constituição afirmado que, havendo a Corte declarado a ilegitimidade constitucional de uma lei, ou ato com a força desta, a norma em foco cessa de produzir seus efeitos do dia seguinte à publicação da decisão. Complementando-o, há, a meu sentir, sem maiores diferenças, o art. $30, n^{\circ} 3^{\circ}$, da Lei $87 / 53$, precisando que as normas declaradas inconstitucionais não podem ter aplicação a partir do dia seguinte ao de sua publicação.

Pelos dispositivos referidos, salta a aparência de que os efeitos da sentença da Corte são ex nunc, isto é. desde o momento de sua pronúncia, tendendo valer apenas para o futuro. Todavia, a interpretação que àqueles vem sendo conferida é mais elástica, de modo que a cessação de eficácia do dispositivo ilegítimo se dá não só ante o processo suspenso perante o juiz a quo, mas perante todas as relações jurídicas pendentes antes da decisão, quer sejam objeto de processo em curso ou não. Ressalvam-se apenas as situações cujos efeitos já se encontram exauridos, tais como as abrangidas pelas sentenças passadas em julgado (sentenza 74/1980), os atos administrativos definitivos, ou os casos nos quais certa faculdade se acha prejudicada pela ocorrência dos termos de prescrição ou de decadência (sentenza 127/1966). Deixa-se entrever, assim, laivos de retroatividade na paralisação das conseqüências da norma inconstitucional. 
Por essa razão, ALESSANDRO PIZZORUSSO aponta que os efeitos de tais decisões não podem ser descritos "falando de efeitos, 'ex tunc', (retroativos), ou de efeitos ex nunc ou pro futuro; a sentença será eficaz frente a todas aquelas relações (anteriores ou posteriores à sua publicação), nas quais a disposição, ou norma declarada inconstitucional, pudesse ser objeto de aplicação". ${ }^{86}$

Merece o cuidado, é bom que não se esqueça, a previsão contida no art. 30 da Lei 87/53, estabelecendo uma importante previsão quanto à abrangência das sentenze d'accoglimento no campo penal, de sorte que, em se tratando de decisão que beneficie o condenado, surtirá aplicação mesmo em havendo trânsito em julgado.

No Brasil, pacificado, de há muito, que a decisão judicial, ao reconhecer uma lei inconstitucional, exara provimento declaratório, pelo que os seus efeitos são ex $\operatorname{tunc}^{87}$.

Excepcionalmente, o Supremo Tribunal Federal, considerando que a tutela da boa fé implica na necessidade de se resguardar efeitos produzidos, durante largo espaço de tempo, pela lei ilegítima, cuja presunção de validade perdurou até o reconhecimento da sua inconstitucionalidade, propendeu a temperar o dogma da nulidade ex tunc ${ }^{88}$. O abrandamento, tanto na esteira do voto do Min. LEITÃO DE ABREU no RE 79.343 - BA, como na das ensinanças de C.A. LÚCIO BITTENCOURT $^{89}$ e MAURO CAPPELLETTI ${ }^{90}$, encontra suporte na jurisprudência da Suprema Corte norte-americana.

Esse entendimento mereceu o beneplácito da Lei 9.868/99. É, ao menos, o que clarividente resulta do seu art. 27 , secundado pelo art. 11 da Lei $9.882 / 99$, relativo à argüição de descumprimento de preceito fundamental, ao dizer que o Supremo Tribunal Federal, ao declarar a inconstitucionalidade de lei ou ato normativo, poderá dispor, louvado em razões de segurança jurídica, ou de excepcional interesse social, que a decisão somente produzirá eficácia a partir do seu trânsito em julgado (ex nunc), ou de outro momento que venha a ser fixado. Se assim permite o legislador, é porque a regra geral é a eficácia retroativa dos reflexos produzidos pela declaração de inconstitucionalidade ${ }^{91}$.

86 "hablando de efectos ex tunc (retroactivos) o de efectos ex nunc ou pro futuro; la sentencia será eficaz frente a todas aquellas relaciones (anteriores o posteriores a su publicación) en las que la disposición o norma declarada inconstitucional pudiesse ser objeto de aplicación". Lecciones de derecho constitucional. Madrid : Centro de Estudios Constitucionales, 1984. t. II. p. 56).

87 RTJ 82/791, 87/758, 89/367 e 102/671.

88 2' T., RE 79.343 - BA, ac. un., rel. Min. LEITÃO DE ABREU, RTJ 82/791; 2 Turma, RE 93.356 - MT, ac. un., rel. Min. LEITÃO DE ABREU, RTJ 97/1.369; 2 Turma, RE 122.202-6-MG, ac. un., rel. Min. FRANCISCO REZEK, DJU de 08/04/94.

89 O controle jurisdicional da constitucionalidade das leis. Brasília : Ministério da Justiça, 1987. p. 147-149. O autor faz referência a alguns precedentes.

90 O controle judicial de constitucionalidade das leis no direito comparado. Porto Alegre : Sérgio Antonio Fabris Editor, 1984. p. 122-124. Da mesma forma, há também citação a outros julgados, de ocorrência posterior àqueles que mencionara o ilustre professor brasileiro.

91 Em caso de decisão que defere cautelar, a Lei 9.868/99 (art. 11, caput), guiando-se pela jurisprudência anterior (RTJ 124/80), afirma que sua eficácia é ex nunc, sem embargo de permitir que tal ocorra de maneira retroativa. 
À míngua de mandamento legal, a Corte Constitucional itálica houve por bem, em algumas situações, nas quais a sentenza d'accoglimento é capaz de provocar fortes repercussões nos planos social e econômico-financeiro, limitar, a partir de determinado instante, a sua eficácia temporal (sentenze 266/1988, 501/1988,01/1991 e 124/1991).

Doutro lado, a sentenza d'accoglimento importa na perda erga omnes do componente eficacial da norma, a não mais permitir o seu emprego por qualquer juiz, ou qualquer sujeito público ou privado. Tal ocorre com a sua publicação na Gazzetta Ufficiale (e além disso, eventualmente, no Bollettino Regionale), enquanto que a comunicação providenciada pela Chancelaria da Corte dirige-se ao juiz a quo.

As decisões do Supremo Tribunal Federal, nesse aspecto, comportam uma distinção, consoante sua pronúncia se dê em via incidental, ou mediante o acolhimento de ação direta. Reconhecida a inconstitucionalidade, pela maioria qualificada de seu plenário, no desfecho, por exemplo, de mandado de segurança de competência originária, ou mediante recurso extraordinário, a decisão, ao inverso do que se verifica na Itália, não basta por si para desembocar na ineficácia da norma. Faz-se, nos termos do art. 52, X, da Constituição Federal, necessária a intervenção do Senado Federal. para deliberar, no âmbito de sua discrição, pela suspensão da execução, no todo ou em parte, da lei declarada inconstitucional pela Excelsa Corte.

Havendo a decisão sido proferida em ação direta de inconstitucionalidade, ou declaratória de constitucionalidade, inclusive em sede de cautelar, a eficácia contra todos da declaração de inconstitucionalidade ou constitucionalidade, respectivamente, depende apenas da deliberação do Supremo Tribunal Federal, tomada com observância do quorum exigido. ${ }^{92}$

Com relação à ação declaratória de constitucionalidade, a Emenda Constitucional 03/93. responsável pela sua introdução em nosso sistema jurídico, agregou a ela o efeito vinculante diante dos demais órgãos do Judiciário e da Administração Pública, dom estendido à ação direta de inconstitucionalidade pela Lei 9.868/99 (art. 28. parágrafo único), a qual, neste ponto, não entra em desinteligência com a Lei Maior. A partir daí, já se pode aventar o possível cabimento de ser ajuizada reclamação também para assegurar-se o respeito às decisões proferidas em ação direta de inconstitucionalidade, principalmente levando-se em conta que tal opção fora, em caráter excepcional, reconhecida pelo Supremo Tribunal Federal na Reclamação $397 .^{.3}$

92 A origem dessa propriedade mirífica defluiu de alteração regimental. procedida pela deliberação constante do Processo Administrativo 4.477-72, para a qual foram determinantes os pareceres dos Ministros MOREIRA ALVES, (sem dúvida o opinamento condutor), XAVIER DE ALBUQUERQUE. THOMPSON FLORES, RODRIGUES ALCKMIN, OSWALDO TRIGUEIRO, LUIZ GALLOTTI e ELOY DA ROCHA, na condição de membros da Comissão de Regimento (cf. DJU de 16/05/77. págs. 3.123-4). Destacável a visão de PAULO LUIZ NETO LOBO (O controle da constitucionalidade das leis e o direito adquirido. Revista de Direito Civil, São Paulo : Revista dos Tribunais, n. 48, p. 104, abr./jun., 1989), ao parecer projetar que tal divisor de águas não se encontra autorizado pelo preceituado no art. 52, X, da Lei Mor.

93 Pleno, ac. un., rel. Min. CELSO DE MELLO, RDA 193/242. 
Razoável, a partir do referimento legal à publicação de tais decisões (arts. 21, caput, e 28, caput, da Lei 9.868/99), que tais reflexos somente se façam ao depois da sua comunicação através dos órgãos da imprensa oficial, porquanto somente a partir daí é que ter-se-á a ficção de que todos os cidadãos e agentes estatais tiveram conhecimento da provisão judicial.

Preciso dizer é que esse discrímen, envolvendo os efeitos erga omnes e vinculante, bem esgrimido entre nós pela pena de JOSÉ CARLOS MOREIRA ALVES ${ }^{94}$, não tem sentido na Itália, havendo a Corte Constitucional, com a sentenza 49/1979, asseverado ser "perfeitamente lógico que seja vetado a todos, a começar pelos órgãos jurisdicionais, de tomar as normas declaradas inconstitucionais como princípio de valoração de qualquer fato ou relação, ainda que anterior à pronúncia da Corte" ${ }^{\text {95. }}$

Característica das sentenze d'accoglimento é a de que, malgrado a atuação da Corte Constitucional haja de conformar-se aos limites da impugnação (art. 27 da Lei 87/53), tem a praxe consagrado a possibilidade de a decisão abarcar disposições não questionadas, cuja presença no sistema ficaria sem sentido com a declaração de inconstitucionalidade da norma objeto do pedido (illegittimità conseguenziale).

Essa não é a postura seguida pelo Supremo Tribunal Federal, como resulta da ADIN 1.187-1-DF, ${ }^{96}$ dirigida contra os arts. 14 e 15 da Lei Complementar 76/93. Ao invés de confirmar a liminar anteriormente deferida, alargando o lastro objetivo da decisão, o Excelso Tribunal, durante o julgamento do mérito, acatou preliminar do Min. MAURÍCIO CORRÊA, voltada para o não conhecimento do pedido, em face deste não haver englobado o art. 16 do referido diploma, dispositivo que, ao sentir do ilustrado julgador, albergava nexo lógico com os artigos cuja compatibilidade vertical fora posta em dúvida.

Consequiência da decisão da Corte Constícucional, no acolher a inconstitucionalidade de norma revogadora, está no fato de que as normas revogadas por aquelas tidas como ilegítimas recuperam a sua vigência. É o que se denomina de reviviscenza. A solução encontra convergência no Brasil, inicialmente em virtude do engenho jurisprudencial, ${ }^{97} \mathrm{e}$, na atualidade, por força do legislador, ao dispor, em compasso com a Lei Maior, que a concessão de medida cautelar, salvo manifestação em contrário, torna aplicável a legislação anterior acaso existente (art. $11, \S 2^{\circ}$, Lei 9.868/99).

94 O controle de constitucionalidade no Brasil. Revista da Procuradoria-Geral da República, São Paulo, Editora Revista dos Tribunais, n. 9, p. 131, jul./dez. 1996.

95 "perfettamente logico che sia vietato a tutti, a cominciare dagli organi giurisdizionali, di assumere le norme dichiarate incostituzionali a canoni di valutazione di qualsivoglia fatto o rapporto, pur se venuto in essere anteriomente alla pronuncia della Corte". (Apud LIVIO PALADIN, Diritto costituzionale. 2. ed. Padova : CEDAM, 1995. p. 770).

96 Pleno. mv, rel. desig. Min. MAURÍCIO CORRÊA, DJU de 30/05/97. Idem na ADINMC 1.851

- AL, ac. un., rel. Min. ILMAR GALVÃO, Informativo - STF $n^{\circ} 121$.

97 RTJ 101/503. 
Em sentido oposto, estão as chamadas sentenze di rigetto, através das quais a Corte Constitucional não reputa fundada a questão de constitucionalidade que the fora submetida, rejeitando a exceção ou o recurso. Em oposição às sentenze d'accoglimento, tais provisões não têm eficácia geral, podendo, quando muito, repercutir no caso concreto, se decorrente de fiscalização incidental.

Um detalhe interessante é o de que a sentenza di rigetto não representa, nem implicitamente, um julgamento de conformidade da lei controvertida com a Constituição, mas, tão-só, restringe-se a examinar a dúvida de inconstitucionalidade nos termos em que formulada. Não adquire, assim, a imutabilidade conatural à coisa julgada, não tolhendo que, mais adiante, a lei venha a ser tida como inconstitucional em outro processo, movido com fulcro em argumentos diversos (sentenza 07/1958).

Aparenta-se tal provisão à decisão que julga improcedente a postulação inserida na ação direta de inconstitucionalidade, de maneira a não impedir seja novamente impugnada a norma que constituíra seu objeto.

Peculiaridade do direito brasileiro está na, esdrúxula e desnecessária, ação declaratória de constitucionalidade, onde o autor, ao dirigir-se ao Supremo Tribunal Federal, colima, justamente, o reconhecimento da compatibilidade do ato normativo indicado com a estrutura constitucional. Mesmo nessa hipótese, evidencia-se ser admissível que, reconhecida a constitucionalidade de uma norma, venha, posteriormente, ser ajuizada ação direta de inconstitucionalidade. Essa possibilidade ficou ressalvada no voto do Ministro CARLOS MÁRIO VELLOSO durante o julgamento da ADC 1-1-DF98.

Importante, outrossim, constatar a correspondência, em nosso direito positivo, de algumas peculiaridades de que são dotadas algumas decisões da Corte Constitucional italiana.

Inicialmente, seria de referir às sentenze additive e sostitutive, ambas compreendidas no universo das sentenze d'accoglimento. As primeiras, também designadas sentenze aggiuntive, notabilizam-se pela peculiar formulação do seu dispositivo, no qual se declara a inconstitucionalidade de uma disposição normativa, justamente na parte em que não prevê algo que, com a sua prolação, passa a integrar a regra jurídica.

Ultimamente, a Corte Constitucional vem impondo algumas restrições a tais decisórios, como a sua interdição em matéria de definição de crimes e penas, em face do princípio da reserva legal (sentenze 73/1977, 71, 148, 177, 232, 295 e $317 / 1983,02 / 1984$ e 249/1988), ou nas extensões de vantagens pecuniárias a determinadas categorias de sujeitos, haja vista a necessidade de suporte financeiro. Desta espécie foi a sentenza $219 / 75$ que, a pretexto de isonomia, inseriu os professores universitários no âmbito de determinado benefício, tendo encontrado resistências no Parlamento, o qual, a princípio, ensaiou desconhecer seu valor vinculativo, em razão do agravo econômico que seria capaz de produzir.

98 Cf. a íntegra do pronunciamento em apenso no livro coordenado por IVES GANDRA DA SILVA MARTINS e GILMAR FERRERIA MENDES (Ação declaratória de constitucionalidade. 1. ed. 2a tiragem. São Paulo : Saraiva, 1 195. p.231-235). 
O Supremo Tribunal Federal rejeita tal prática. Em torrencial jurisprudência, sustenta que o Judiciário, ao fiscalizar a compatibilidade das leis com a Constituição, atua como legislador negativo, não lhe sendo dado alargar a incidência do comando impugnado, ainda que para sanar violação ao cânon da igualdade ${ }^{99}$. Para aquele a saída correta está na declaração de inconstitucinalidade, se requerida, do dispositivo que implicou em trato desigualitário.

Isso é facilmente evidenciado com o reconhecimento, em liminar na ADIN $2.251^{100}$, da inconstitucionalidade do art. $4^{\circ}$ - A da Lei 8.437/92, na redação da MP $1.984 / 2000$, o qual previa a possibilidade de medida cautelar em ação rescisória, restringindo-a em prol da União, Estados, Municípios, suas autarquias e fundações. A nosso sentir, perdeu-se uma grande oportunidade para a construção da teoria das sentenças aditivas em nosso país, precisamente por a espécie não implicar em extensão de dispêndios ao erário público.

Mediante as sentenze sostitutive ou modificative, a pronúncia de inconstitucionalidade acarreta a inclusão de uma disposição no lugar daquela tida como inválida. Pode-se mencionar a sentenza 15/1969, ao declarar inconstitucional o art. $313, \mathrm{n}^{\circ}$ $3^{\circ}$, do Código Penal italiano, na parte em que atribuía ao Ministro da Justiça a autorização para o processo por crime de vilipêndio à Corte Constitucional, antes de fazê-lo ao próprio Tribunal. Com a sua atividade, restou substituída a regra ilegitimamente enunciada (competência do Ministro da Justiça para autorizar a instauração do processo) pela indevidamente omitida (competência à Corte autorizar a persecução criminal). Mais recentes, as sentenze 168/1972, 11/1973, 15 e 86/1977, 01/1985, 182 e 235/1988).

Não há, pelo nosso conhecimento, registro de discussão idêntica nos anais do Supremo Tribunal Federal. Não obstante, pelo que se percebe da posição deste, ao rejeitar a possibilidade das sentenze additive, é de concluir-se, com maior margem de acerto, pela não admissibilidade das sentenze sostitutive no sistema brasileiro de controle da constitucionalidade, máxime quando se percebe que estas, mais do que aquelas, sofre a crítica ácida da doutrina, no rumo de que tal função se qualifica como substancialmente legislativa. Essa futura tendência já pode ser esboçada através da ADIN 1.822-4-DF ${ }^{101}$, onde a pretensão de eliminar do inciso I do $\S 2^{\circ}$ do art. 47 , da Lei 9.504/97, a expressão "um terço", poderia implicar na alteração do sentido da norma atacada.

Em muitas ocasiões, a Corte Constitucional, sem acolher ou desacolher o pedido de forma peremptória, lança mão de nova exegese do texto impugnado, com vistas a delimitar neste a presença de conteúdo normativo que não colida com a Lei Máxima. Pode, com esse mecanismo, a Corte fixar que haveria inconstitucionalidade caso o dispositivo fosse interpretado de uma determinada maneira (sentenze inter-

99 Pleno, mv, ADINMC 1.755-DF, rel. Min. NELSON JOBIM, julg. em 15/10/98, Informativo STF n ${ }^{\circ}$ 127; Pleno, ADIN 652-MA, ac. un., rel. Min. CELSO DE MELLO, RTJ 146/461.

100 Plenário, ac. un., rel . Min. SYDNEY SANCHES, Informativo - STF 199.

10ı Pleno, ac. un., rel. Min. MOREIRA ALVES, DJU de 10/12/99. 
pretative d'accoglimento), ou estabelecer a não existência de ilegitimidade se aquele for compreendido na direção que indica (sentenze interpretative di rigetto).

Antes mesmo da entrada em vigor da Constituição de 1988, já havia o Supremo Tribunal Federal, na Rp. 948-SE ${ }^{102}$, perfilhado o caminho de que não se decreta inconstitucionalidade quando se puder encontrar na norma combatida um significado que a harmonize com a Constituição.

Na Rp. 1.417-7-DF ${ }^{103}$, igualmente vivenciada sob o jugo da Lei Maior revogada, - Augusto Pretório, em aresto de percuciente motivação, persistiu no manuseio da interpretação conforme à Constituição, situando-a o Min. MOREIRA ALVES, ao desincumbir-se da relatoria, como integrante do universo do controle da constitucionalidade, ao invés de simplesmente reduzi-la a uma regra exegética. Aproveitando a oportunidade, o referido magistrado deixara claro que a interpretação conforme é inviável toda vez que as tentativas de compatibilização do preceito discutido com a Lei Maior contrastar com o sentido inequívoco que o legislador pretender conferirIhe.

Durante a atual ordem magna, são vários os exemplos de decisões interpretativas $^{104}$ até a sua positivação explícita no art. 28 , parágrafo único, da Lei 9.868/99.

Outros espécimes, de que se tem valido a Corte Constitucional da Itália, são as: a) sentenze legislative (ou de indirizzo), em que, ao depois de verificada a ausência de regulamentação normativa reclamada constitucionalmente, aquela estatui orientações a serem observadas pelo legislador, como ocorreu com a sentenza $225 / 1974$, ao fixar uma série de cautelas, relativas ao sistema de radiodifusão sonora e de sons e imagens, que, posteriormente, constaram da Lei de 14 de abril de 1975; b) sentenze-monito, as quais, estando bastante próximas das anteriores, estatuem condições à atividade legislativa.

Não se encontra, no seio da atividade do Supremo Tribunal Federal, qualificativos semelhantes para os seus julgados. Isso não quer dizer, contudo, esteja excluída a possibilidade de aquele órgão, ao interpretar a Lei Maior, utilizar como técnica a de traçar recomendações ao legislador. Invoque-se a ADin 1434-SP, ${ }^{105}$ em que o Augusto Pretório, demais de enfatizar depender de lei a materialização da isonomia estipendiária do art. $39, \S 1^{\circ}$, da Constituição Federal, em sua redação originária, estabeleceu competir ao legislador tomar em consideração a igualdade ou similitude do conteúdo ocupacional de determinados cargos públicos, além da circunstância de que tais núcleos de competência devam situar-se na estrutura da Administração Direta.

De destacar, nos termos do art. 137, $\mathrm{n}^{\circ} 3^{\circ}$, da Lei Maior de 1947, não estarem sujeitas a qualquer impugnação as decisões tomadas pela Corte Constitucional. Esta,

102 Pleno, ac. un., rel. Min. MOREIRA ALVES, RTJ 82/51.

103 Pleno, ac. un., DJU de 15/04/88.

104 Pleno. ADIN 234-1/600-RJ, ac. un., rel. Min. NÉRI DA SILVEIRA, DJU de 15/09/95: Pleno, ADIN 1.348-3-RJ, mv, rel. Min. OCTÁVIO GALLOTTI, DJU de 07/12/95; Pleno, ADIN 1.194-4DF, ac. un., rel. Min. MAURÍCIO CORRÊA, DJU de 29/03/96.

105 Pleno, mv, rel. Min. CELSO DE MELLO, DJU de 22/11/96, p. 141. 
após rejeitar o conhecimento de demandas onde vergastado preceito que já declarara inconstitucional (sentenze 93/1986, 86/1987, 265/1987, 431/1988 e 224/1989), temse limitado a admitir pleitos de correção de seus acórdãos, em decorrência de omissão ou erros materiais (sentenze 77/1988 e 178/1989).

Proximidade há com o sucedido em nossas plagas, em sede de fiscalização pela via principal, de modo a enunciar 0 art. 26 da Lei 9.868/99: " A decisão que declara a constitucionalidade ou a inconstitucionalidade da lei ou do ato normativo em ação direta ou em ação declaratória é irrecorrivel, ressalvada a interposição de embargos declaratórios, não podendo, igualmente, ser objeto de ação rescisória".

\section{IX - Considerações finais}

Ao encerrar este trabalho, abandonarei a prática, comum em trabalhos científicos, de resumir os temas expostos em cada uma das suas partes. Mais aconselhável, em se tratando de microcomparação procedida entre sistema estrangeiro e nacional, proceder-se à formulação, a partir do paradigma indicado, de propostas de aperfeiçoamento do modelo positivo de controle da constitucionalidade, cuja adoção ora não prescindirá de reforma constitucional, ora poderá ser materializada pela senda interpretativa.

Quanto às sugestões, para a implementação das quais se torna indispensável a mudança da Lei Básica, advém, em primeiro lugar, a relativa à concentração, em favor de determinado órgão, integrado no Judiciário, e cujos membros, no que for possível, ostentem as prerrogativas e vedações assecuratórias da imparcialidade da magistratura (que poderá recair no Supremo Tribunal Federal, haja vista a criação do Superior Tribunal de Justiça), da competência de julgar dos litígios, para cuja solução seja relevante a discussão em torno da compatibilidade vertical de lei ou ato normativo.

A vantagem da inovação estaria em prestigiar-se a certeza do direito, de modo a evitar-se, dados os inúmeros juízos e tribunais, uma multiplicidade de interpretação sobre uma mesma norma, com enorme contribuição para o desenlace ágil dos feitos.

Substituir-se-ia, assim, a atividade dos juízes e tribunais ordinários pela de uma corte constitucional, na esteira da prática adotada pela maioria dos países do oeste europeu do segundo pós-guerra ${ }^{106}$, a qual, bem sucedida. espraiou-se para grande parte das constituições dos países que outrora seguiam o socialismo soviético ${ }^{107}$.

Assim, quando o magistrado se defrontasse, em um processo sob a sua jurisdição, com uma forte dúvida de constitucionalidade, poderia, a pedido das partes, do

106 Cf. a Lei Fundamental de Boon de 23/05/49 (ants. 93 e 94), as Constituições da República Portuguesa de $02 / 04 / 76$, na forma estabelecida pelas sucessivas revisões (arts. $277^{\circ}$ a $283^{\circ}$ ), e da Espanha de $29 / 12 / 79$ (ants. $159^{\circ}$ a $165^{\circ}$ ).

107 Dentre vários exemplos, cite-se as Constituições da República da Eslovênia de 23/12/91 (Parte Oitava, arts. 160 a 167), da República da Eslováquia de 01/09/92 (Parte Sétima, Cap. I, arts. 124 a 140), da República Tcheca de 16/12/92 (Cap. IV, arts. 83 a 89). 
Ministério Público, ou de ofício, remeter o exame da questão ao tribunal para tais assuntos competente. Pronunciando-se este, a mensagem contida em sua decisão permitiria, demais da solução da questão analisada, como das demais relações jurídicas não estabilizadas.

Nos moldes italianos, a estruturação desse organismo dependeria, ao menos, de duas outras providências normativas. A uma, do estabelecimento da investidura temporária dos seus membros, através de mandato (possivelmente entre oito a dez anos), a fim de permitir uma adaptação da sua jurisprudência à alteração das circunstâncias sociais. A outra, seria a participação direta do Judiciário e do Legislativo na escolha dos seus membros, a qual não mais continuaria dependente quase unicamente da vontade da chefia do Executivo, cautela a resultar em garantia de maior independência do tribunal constitucional.

De conseguinte, outra necessidade de modificação no texto da Lei Fundamental, in casu derrogatória, seria a exclusão da anacrônica competência do Senado Federal para determinar, em juízo discricionário, a suspensão da execução da lei, ou ato normativo, declarado inconstitucional pelo Supremo Tribunal Federal.

Independentemente da intervenção do poder constituinte reformador, o engenho jurisprudencial poderia, inspirado pelos eflúvios, conduzir a alguns esmeros, tais como: a) o conhecimento de ação direta de inconstitucionalidade mesmo nos casos de leis antecedentes à Constituição, uma vez não serem excludentes, na superação de contradições no sistema jurídico, os critérios da hierarquia (da ilegitimidade constitucional) e cronológico (revogação); b) a utilização, no controle mediante ação direta, da técnica de ponderação de interesses, a fim de verificar, com maior profundidade, se a restrição de direito ou liberdade constitucional se assenta em bases razoáveis; c) validar, mediante a interpretação conforme à Constituição, a previsão de efeito vinculante outorgada à ação direta de inconstitucionalidade pelo art. 28 , parágrafo único, da novel Lei $9.868 / 99$, igualando os efeitos do seu julgamento de procedência aos das sentenze d'accoglimento; d) o reconhecimento da possibilidade do dispositivo da ação direta, ao acatar o pedido, abarcar preceitos normativos não impugnados quando a eficácia destes depender da norma invalidada (illegittimità conseguenziale); e) a adoção das decisões aditivas nas hipóteses onde não se cogite a realização de gastos desprovidos de cobertura orçamentária. 